\title{
1 A NEW KAOLIN DEPOSIT IN WESTERN AFRICA: MINERALOGICAL AND 2 COMPOSITIONAL FEATURES OF KAOLINITE FROM CALUQUEMBE (ANGOLA)
}

3 Esperança Tauler ${ }^{1}$, Jingyao $\mathrm{Xu}^{1 *}{ }^{*}$, Marc Campeny $^{1,2}$, Sandra Amores ${ }^{1}$, Joan Carles 4 Melgarejo $^{1}$, Salvador Martinez ${ }^{1}$ and Antonio O. Gonçalves ${ }^{3}$

5

$6{ }^{1}$ Departament de Mineralogia, Petrologia i Geologia Aplicada, Facultat de Ciències de la Terra, Universitat de

$8{ }^{2}$ Departament de Mineralogia, Museu de Ciències Naturals de Barcelona, Barcelona, Spain

$9{ }^{3}$ Departamento de Geologia, Universidade Agostinho Neto, Luanda, Angola

*e-mail: jingyao.xu@ub.edu

rocks have been discovered in the Caluquembe area, Huíla province, Angola. To determine accuracy of analysis and to evaluate the samples kaolinite grade, it was used full profile

Rietveld refinement by X-Ray Powder Diffraction (XRPD) and Gravimetric Thermal Analysis (TGA). Caluquembe kaolin is mainly comprised of kaolinite (44 to 93 wt. \%), quartz (0 to 23 wt. \%) and feldspar (4 to 14 wt. \%). AGFI Crystallinity Index, calculated by XRPD profile refinement, indicates low and medium defect kaolinite. Kaolinite particles show a platy habit and they are stacked together forming 'booklets' or radial aggregates, also occurring as fine anhedral particles in a finer-grained mass. Muscovite-kaolinite intergrowths have also been found. Whole-rock chemical composition was analyzed, including major, trace, and Rare Earth Elements (REE). Chondrite and Upper Continental Crust normalized REE patterns show the same tendency for all samples, with a significant enrichment in Light Rare Earth Elements (LREE). Mineralogical and compositional features of the Caluquembe kaolin indicate that it is a suitable material in the manufacture of structural products, such as bricks, pavers and roofing tiles. In addition, REE significant contents of the Caluquembe kaolin can be considered as a potential future target of mining exploration.

Key Words: Caluquembe, Angola, kaolinite, AGFI, REE. 
Kaolinite $\mathrm{Al}_{2} \mathrm{Si}_{2} \mathrm{O}_{5}(\mathrm{OH})_{4}$ is a clay mineral, structurally classified as 1:1 layer type,

with a crystalline structure comprised of tetrahedral and octahedral sheets (Young and Hewat, 1988; Moore and Reynolds, 1997; Bish, 1993). It belongs to the spatial group $C \overline{1}$ with $a=5.154 \AA, b=8.942 \AA, c=7.402 \AA, \alpha=91.69^{\circ}, \beta=104.61^{\circ}$ and $\gamma=89.92^{\circ}$ (Bish, 1993).

Kaolinite is classified within the kaolin subgroup, which also includes other minerals such as dickite, nacrite and a hydrated form of halloysite (Guggenheim et al., 2006). Structural differences between these mineral phases are based on their interlayer shift and the location of the octahedral vacancy in successive layers (Bailey, 1980).

Kaolinite is a valuable and versatile industrial mineral with classical applications in the production of bricks, ceramics, paint coatings, paper, and plastic. It also has relatively new applications in catalysis and organic reactivity as well as in the pharmaceutical industry, where it is used in the design of clay-polymer nanocomposites and films (Heckroodt, 1991; Murray, 1999c; Murray, 2000; Detellier and Schoonheydt, 2014; Phipps, 2014; Pruett, 2016; Dedzo and Detellier, 2016; Nguie et al., 2016; Mansa et al., 2017).

In 2015, world kaolinite production was around 34 million tons (Mt), mainly led by the United States, Germany, Czech Republic and China, among other countries (Flanagan, 2016).

Kaolin deposits are classified as primary, secondary, or tertiary depending on their parent lithology and corresponding alteration processes (Dill, 2016). In primary deposits, the parent lithology is a feldspar-rich magmatic rock - mainly granitic or acid 
55 volcanic - and the formation of kaolinite is related to feldspar alteration due to

hydrothermal fluid circulation and/or the development of weathering processes (Schroeder and Erickson, 2014). On the other hand, sedimentary processes generate secondary deposits, mainly comprised of detrital clays (Schroeder and Erickson, 2014). Tertiary deposits are generated by very low regional metamorphism developed in argillaceous sediments or sands (Dill, 2016).

Angola has significant and large mineral resources. However, for more than forty years, the Angolan independence and civil wars (1961 - 2002) prevented systematic mining exploration in the country. Nowadays, known mineral resources in Angola include: beryllium, clays, copper, gold, gypsum, iron, lead, lignite, manganese, mica, nickel, phosphates, silver, tungsten, uranium, vanadium and zinc, among others (Bermúdez-Lugo, 2014). However, diamonds are the most economically relevant mineral resource in the country and account for about $5 \%$ of worldwide production.

In the case of kaolin, significant deposits have been documented in several regions in Angola (Ekosse, 2010). Most of them are related to weathering of anorthosites from the Kunene anorthositic complex, but systematic studies of these kaolin deposits are still very scarce. The only significant studies were carried out by Gomes et al. (1994) and Saviano et al. (2005) in the Mevaiela kaolin deposit, located near the village of Quihita in SE Angola.

In the Caluquembe area (Huíla province, Angola), (Fig. 1) extensive kaolin outcrops associated to weathering of Eburnean granitic rocks were recently discovered. This study presents the most relevant mineralogical and compositional features of Caluquembe kaolinite. It has been determined the kaolinite grade of the deposit by processing XRPD spectra using full profile Rietveld refinement and testing 
the accuracy of the results by TGA. This study also includes kaolin major and trace elements compositions, with especial interest in the distribution of Rare Earth Elements (REE), considering that a significant number of REE deposits worldwide are related to weathering of granitic rocks (Nyakairu and Koeberl, 2001; Nyakairu et al., 2001; Njoya et al., 2006; Bao and Zhao, 2008; Galán et al., 2016; Sanematsu and Watanabe, 2016) or from sedimentary rocks (Kadir and Kart, 2009; Elliott et al., 2018). The results obtained may be considered as preliminary evaluation guidelines for future mining exploration of kaolin and accessory REE's in the Caluquembe area.

7

8

\section{GEOLOGICAL SETTING}

(1)

The Caluquembe area is located in the Huila province (SW Angola), approximately $180 \mathrm{~km}$ NE from Lubango and $570 \mathrm{~km}$ SE of Luanda, Angola's capital (Fig.1).

Angola's structural framework is generally represented by the Kasai and Congo cratons, which correspond to continental blocks stabilized during the Mesoproterozoic orogeny (Hanson, 2003; Jelsma et al., 2011).

The southwestern part of the Congo Craton comprises the Angolan Shield where the occurrence of widespread Paleoproterozoic crust - dominated by granitoids - has been identified together with a limited amount of Archaean crust (de Carvalho et al., 2000; McCourt et al., 2013) (Figure 1a).. This basement terrane is intruded by the anorthositic Kunene Complex (Ashwal and Twist, 1994; Mayer et al., 2004), a set of Mesoproterozoic red granites, and it is also unconformably overlain by supracrustal sequences. 

that form the Angolan Shield, known as the Central Eburnean Zone (de Carvalho et al., 2000; Jelsma et al., 2011; McCourt et al., 2013). In this domain, paleoproterozoic granitoids are the dominant lithologies (Figure 1). However, more recent lithologies such as Eburnean granitoids linked to the Namib thermotectonic event are also found outcropping in this area (de Carvalho et al., 2000). The predominant lithology in the sampled Caluquembe area is the regional Chicala alkaline granite (c. 1700-1650 Ma), outcropping in association with porphyritic granites and other Eburnean granites such as the Yuabre and Quibala granites (Figure 1). Hypabyssal rocks such as dolerites, norites, and olivine basalts also occur across the region - related to anorogenic magmatism that occurred in the middle and late Proterozoic and also towards the end of the Cretaceous, during the Wealdenian reactivation of the Angolan platform (c. 130100 Ma, Silva and Simões, 1980/1981). weathering profiles.

SAMPLING and METHODS

In the present work, were studied a set of 34 samples obtained in extensive weathering profiles developed on granitic rocks in the Caluquembe region (Figure 2).

125 The studied area is around $20 \mathrm{~km}^{2}$ and sampling was mainly focused on the available outcrops located along river margins. 

examined on polished thin sections with a Nikon Eclipse LV100 POL microscope and an ESEM Quanta $200 \mathrm{FEI}$ XTE 325/D8395 scanning electron microscope with energy dispersive X-ray spectroscopy (SEM-EDS) at the Scientific and Technological Centers of the University of Barcelona (CCiTUB) (Barcelona, Catalonia, Spain). Particle size was measured with a Beckman Coulter LS Particle Size Analyzer. To avoid sample flocculation and consequent erroneous measure of grain size distribution, approximately 0.5 grams of dry sample were diluted in a dispersing analysis the obtained solution was agitated during 24 hours. This preparation was carried out in Department of Earth and Ocean Dynamics from the Earth Sciences Faculty of the University of Barcelona (Barcelona, Catalonia, Spain).

Microprobe analyses (EMPA) were performed over selected areas on representative polished thin sections. Analyses were carried out with a JEOL JXA-8230 at the CCiTUB. Analytical conditions were a low voltage of $20 \mathrm{kV}$ (in order to excite the weaker lines K, L of certain heavy elements those can present spectral interferences), $10 \mathrm{nA}$ beam current, $2 \mu \mathrm{m}$ beam diameter and counting time of 10 seconds per element.

Kaolin samples, after dried, were crushed for X-ray Powder Diffraction (XRPD) and Thermal analyses (DTA-TGA) only using agate mortar.

XRPD data were collected with a Panalytical X'Pert PRO MPD X-ray diffractometer with monochromatized incident $\mathrm{Cu} \mathrm{K}_{\alpha 1}$ radiation at $45 \mathrm{kV}$ and $40 \mathrm{~mA}$, equipped with a PS detector with amplitude of $2.113^{\circ}$ located at the CCiTUB. Patterns were obtained by scanning random powders from $4^{\circ}$ to $80^{\circ}(2 \theta)$ on samples crushed in 
an agate mortar to a particle size below $40 \mu \mathrm{m}$ or on oriented mounts. The oriented clay mineral aggregates were prepared by glass slide method before separating clay minerals from clasts (Moore and Reynolds, 1997). Datasets were obtained using a scan time of 50 seconds at a step size of $0.017^{\circ}(2 \theta)$ and variable automatic divergence slit. Quantitative mineral phase analyses were obtained by full refinement profile using XRPD. The software used was TOPAS V4.2 (2009). Thermal analyses were carried out by simultaneous DTA-TGA, using a Netzsch instrument (STA 409C model) located at the Department of Mineralogy, Petrology and Applied Geology from the Earth Sciences Faculty of the University of Barcelona (Barcelona, Catalonia, Spain). Analyses were carried out under a temperature range of 25 to $950^{\circ} \mathrm{C}$, atmospheric pressure, constant flow rate of $80 \mathrm{~mL} / \mathrm{min}$, and at a heating rate of $10{ }^{\circ} \mathrm{C} / \mathrm{min}$ in an $\mathrm{Al}_{2} \mathrm{O}_{3}$ crucible. The sample amount used was approximately 80 mg. Laboratories Ltd., (Ancaster, Ontario, Canada) with the analytical package "4Litho", using fusion inductively coupled plasma emission (FUS-ICP) and inductively coupled plasma emission mass spectrometry (ICP-MS) (for details see http://www.actlabs.com).

RESULTS

Kaolin petrography

Kaolin samples are made up of soft powder with white to gray, pale yellow and pale brown colors, containing some consolidated fragments. 

predominant whereas clay and sand fractions are less abundant. Therefore, 4.9 to 8.8 vol. \% of kaolin particles are less than $2 \mu \mathrm{m}$ in size; 54.1 to 75.1 vol. \% between $2 \mu \mathrm{m}$ and $63 \mu \mathrm{m} ; 12.6$ to 17.9 vol. \% between $63 \mu \mathrm{m}$ and $125 \mu \mathrm{m}$; and 3.3 to 12 vol. \% between $125 \mu \mathrm{m}$ and $250 \mu \mathrm{m}$. (groundmass) composed by muscovite and kaolinite (Figure 3a). Quartz occurs as irregular fragments of $500 \mu \mathrm{m}$ in size with typical angular borders. Microcline anhedral grains are up to $200 \mu \mathrm{m}$ in diameter and they are commonly altered to cryptocrystalline kaolinite. Plagioclase has grain size of less than $100 \mu \mathrm{m}$ and is also altered to sericite. SEM-BSE images show that in the finer-grained mass, muscovite occurs as tabular habit crystals (50 $\mu \mathrm{m}$ in length) while particles of kaolinite often show a platy habit and are stacked together forming "booklets" or radial aggregates, even both phases can be also found as very fine anhedral particles (Figure $3 b$ ). Some particles of muscovite are separated by cleavage (Figure 3c). Kaolinite is also found as muscovite-kaolinite intergrowths (up to $50 \mu \mathrm{m}$ in length), which could be distinguished using EDS microanalysis (Figure 3b). Phosphate enriched in LREE (Light Rare Earth 3d).

$X$-ray powder diffraction (XRPD)

The quantitative analysis of 26 whole-rock random powders (XRPD) show that samples are mainly comprised of kaolinite (50.4 to 87.0 wt. \%), quartz (0 to 23.5 wt. 
wt. \%) (Table 1). Scarce hematite ( $<1$ wt. \%) is also found in some samples, except in sample KP1, which contains a significant amount of accessory minerals, with 1.6 wt. \% of hematite and 2.4 wt. \% of calcite. The shallower samples (KA, KU3, KU6B, KKL17B, KL13-2, L-1 and L-2) are richer in kaolinite than samples obtained from base of the profiles. For instance, samples KU6B (shallow) and KU6D (deep) from the same outcrop contain 71.5 wt. \% and 58.9 wt. \% of kaolinite, respectively (Table 1 ).

XRPD profile refinement for sample KL13-2 reveals a significant percentage of kaolinite (84.2 wt. \%), less than 1 wt. \% of quartz, and very low muscovite content (2.9 wt. \%) (Figure 4a). Sample KC12 has higher quartz (23.5 wt. \%) and muscovite contents (21.3 wt. \%), and less kaolinite (50.4 wt. \%). A negative correlation $\left(R^{2}=0.67\right)$ between the wt. \% content of kaolinite and muscovite plus K-feldspar is evident in the analyzed samples (Figure 5).

The average crystallite size for kaolinite is $15-35 \mathrm{~nm}$, calculated from the profile refinement by XRPD.

Five samples containing illite and three samples containing smectite were identified (Table 2). The three smectite-bearing samples (KL6E, KL8E*, and KLB10) are located in the deepest part of the outcrop, containing a low kaolinite grade (Table 2). Illite-bearing samples KK13 and KK11A also contain goethite: 12.9 wt. \% and 22.9 wt. $\%$, respectively.

The XRPD pattern of three samples show the $d_{00 l}$ of illite, muscovite, smectite, and kaolinite in the region of $4^{\circ}$ to $15^{\circ}(2 \theta)$ (Figure 6$)$. The $d_{002}$ band for illite at $10.03 \AA$ was broader and less intense than that for muscovite at $d_{002}=9.97 \AA$. A broad and low intensity maximum for smectite is at $d_{001}=14.9 \AA$. The $d_{001}$ of kaolinite at $7.14 \AA$ shows 
no appreciable differences in the XRPD profile of these samples and is narrow and intense.

In the XRD pattern of oriented mounts samples is possible to distinguish

kaolinite, the reflections $\mathrm{d}_{00 \text { l }}$ disappeared after heating to $550^{\circ} \mathrm{C}$. After ethylene glycol

treatment there is not variations detected. In contrast, the XRD patterns of oriented mounts of samples with smectite have significant changes. The peak at $d_{001}=14.9 \AA$ changes to $17 \AA$ when solvated in ethylene glycol, and changes to $10 \AA$ when the sample is heated to $550{ }^{\circ} \mathrm{C}$. Samples with illite show only a slight expansion of the broad reflection at $\mathrm{d}_{002}=10.03 \AA$ when solvated in ethylene glycol, indicating a small proportion of expanded clay (Thorez, 1975; Moore and Reynolds, 1997).

The physical properties of kaolin, such as whiteness, abrasiveness, particle size, shape and distribution, viscosity, and rheology vary depending on the genetic conditions of the deposits. Kaolinite Crystallinity Index $(\mathrm{KCl})$ may be significant to the calculation of the degree of crystal perfection in kaolinite, which is a necessary parameter to evaluate kaolinite quality for industrial applications, in addition to the plasticity correlation. In the XRPD pattern, reflections $020,1 \overline{1} 0$ and $11 \overline{1}$ were detected in the region of $20^{\circ}$ to $23^{\circ}(2 \theta)$. These reflections are sensitive to random and interlayer displacements and allow calculating for $\mathrm{KCl}$ (HI from Hinckley, 1963; IK from Stoch, 1974; AGFI from Aparicio et al., 2006). The Hinckley crystallinity index (HI, Hinckley, 1963) is one of the most widely used indices. Normal values range from $<0.5$ (disordered) to 1.5 (ordered). The calculated $\mathrm{HI}$ index in the region of $20^{\circ}$ to $23^{\circ}(2 \theta)$ is 242 of 1.06 in sample KA, 1.05 in sample KC12, and 1.09 in sample KL12A. The HI of 243 Caluquembe kaolin is generally higher than reported in other kaolin deposits worldwide such as the sedimentary kaolin from Warren (Georgia, USA) with $0.56 \mathrm{HI}$ or 
the kaolin from Montecastelo (Spain) presenting $1.00 \mathrm{HI}$ (Aparicio et al. 2006). The IK index or Stoch index (Stoch, 1974) is measured in the same zone as for $\mathrm{HI}$, and the normal values range from $>1.0$ (disordered) to $<0.7$ (ordered). The calculated IK index in the region of $20^{\circ}$ to $23^{\circ}(2 \theta)$ is 1.04 (disordered) in sample KL12A.

According to Aparicio and Galan (1999), the $\mathrm{KCl}$ can only be determined as an approximate value. Kaolinite maximums by XRPD are close to the muscovite and quartz maximums in the region of $20^{\circ}$ to $23^{\circ}(2 \theta)$ (Figure $4 \mathrm{~b}$ and $4 \mathrm{c}$ ). Aparicio et al. (2006) present a new AGFI (Aparicio-Galán-Ferrel Index) based on the additional processing to decompose overlapping peaks detected in the region of interest with the software MacDiff (Petschick, 2004).

Peak intensities of $020,1 \overline{1} 0$ and $11 \overline{1}$ in kaolinite has been determined through full profile refinement by XRPD and the software Topas V4.2 in samples from Caluquembe. Sample KC12 has quartz (24 wt. \%) and muscovite (21 wt. \%), with an AGFI of 1.35 (Figure 4b). Sample KA has $<1$ wt. \% of quartz and 9 wt. \% of muscovite, and an AGFI of 1.06 (Figure 4c). Sample KL12A has 5 wt. \% of quartz and 20 wt. \% of muscovite and an AGFI of 1.19. According to Aparicio et al. (2006), these samples can be classified as low and medium defect kaolinite. Similar data were obtained by at $540.3^{\circ} \mathrm{C}$ in sample KL132, confirming the dehydration of kaolinite (Mackenzie, 1957; Liu et al., 2015). Samples have a mass loss between 6.2 and 13.0 wt. $\%$ up to $650 \circ \mathrm{C}$ in 
269 TGA curve. Samples with higher kaolinite contents show a more significant mass loss.

270 The amount of kaolinite calculated by mass loss is between 44.3 and 92.9 wt. \% (Table

271 1).

272

Correlation between TGA and XRPD

Thermal analyses have been carried out to check the quantitative results of

274 mineral phases calculated by XRPD using the correlation between the calculated wt. \% of kaolinite in the profile refinement by XRPD and the calculated wt. \% of kaolinite in TGA (Figure 8). Samples containing more kaolinite also have higher mass loss that shows a positive correlation $\left(R^{2}=0.75\right)$. The model proposed demonstrates an adequate accuracy for the quantification of kaolinite and shows that material sampled closer to the surface is richer in kaolinite than samples from the deeper part of the profile. The quantitative results of samples containing illite and smectite give more inaccurate values considering that the thermal characteristics of kaolinite are influenced by the presence of smectite and illite.

Kaolin geochemistry $\mathrm{SiO}_{2}, 36.31 \mathrm{Al}_{2} \mathrm{O}_{3}, 0.58 \mathrm{MgO}, 0.03 \mathrm{Na}_{2} \mathrm{O}, 0.10 \mathrm{TiO}_{2}, 0.85 \mathrm{Fe}_{2} \mathrm{O}_{3}, 0.03 \mathrm{MnO}, 0.04 \mathrm{BaO}$,

$0.07 \mathrm{CaO}, 0.05 \mathrm{~K}_{2} \mathrm{O}$ wt. \%. The average structural formula based on 14 oxygens is the following: $\left(\mathrm{Al}_{3,77} \mathrm{Fe}^{3+}{ }_{0,05} \mathrm{Mg}_{0,06}\right)_{3.9} \mathrm{Si}_{4,0} \mathrm{O}_{10}(\mathrm{OH})_{8}$.

Major-, trace- and REE concentrations have been obtained from six representative samples from the Caluquembe area (Table 3 and 4). Two kaolin samples from Uganda (Nyakairu and Koeberl, 2001), one from Cameroon (Njoya et al., 2006) 
in Tables 3 and 4. Sa Bandeira granite has a very similar composition to the granites that outcrop in the Caluquembe area (Montenegro de Andrade, 1954).

Major elements generally show a different trend in the altered sample compared to the parent rock (Table 3 ). The $\mathrm{SiO}_{2}$ trend of Caluquembe kaolin is decreasing and the $\mathrm{Al}_{2} \mathrm{O}_{3}$ trend is increasing compared to the granite from Sa Bandeira. $\mathrm{SiO}_{2}$ is high for all samples ranging between 45.35 and 63.24 wt. $\% . \mathrm{Al}_{2} \mathrm{O}_{3}$ contents lie between 21.89 and 32.24 wt. \%. $\mathrm{Fe}_{2} \mathrm{O}_{3}$ is between 1.36 and 4.25 wt. \%. $\mathrm{K}_{2} \mathrm{O}$ is between 1.16 and 4.03 wt. \%. $\mathrm{TiO}_{2}$ is between 0.49 and 0.86 wt. \%. Other remaining oxides $(\mathrm{Mn}$, $\mathrm{Mg}, \mathrm{Ca}, \mathrm{Na}$ ) are only present as traces (<0.2 wt. \%). Loss on ignition (LOI) values are between 7.80 and 13.69 wt. \%.

The most abundant trace elements are: Zr from 162 (sample L1) to 430 (sample K6E) ppm; Ba from 222 (sample K6E) to 1090 (sample KL13-2) ppm; Rb from 54 (sample KL13-2) to 206 (sample KLB 10) ppm. Other trace elements such as Sc, V, Cr, $\mathrm{Co}, \mathrm{Ni}, \mathrm{Cu}, \mathrm{Zn}, \mathrm{Ga}, \mathrm{Sr}, \mathrm{Y}, \mathrm{Nb}, \mathrm{Hf}, \mathrm{Pb}$, Th, and $\mathrm{U}$ are usually less than $100 \mathrm{ppm}$. As, Mb, $\mathrm{Ag}, \mathrm{In}, \mathrm{Sn}, \mathrm{Sb}, \mathrm{Cs}, \mathrm{Ta}, \mathrm{W}$ and $\mathrm{Bi}$ are less than $5 \mathrm{ppm}$ (Table 4).

REE contents in kaolin samples vary from 130 ppm (sample L1) to 564 ppm (sample KL13-2). REY (REE+Y) range between 142 ppm and 624 ppm. LREE (Light Rare Earth Elements) (La, Ce, Pr, Nd, Sm, Eu) range from 524 to 122 ppm while HREE (Heavy Rare Earth Elements) (Gd, Tb, Dy, Ho, Er, Tm, Yb, Lu) range from 40 to 8 ppm (Table 4). The C1 chondrite-normalized REE plots (Figure 9a) (McDonough and Sun, 1995) are roughly parallel and characterized by negative slopes as a result of enrichment in the LREE relative to HREE. The normalization via upper Continental Crust (UCC, Rudnick and Gao, 2003) is presented in Figure 9b. In general, Caluquembe samples present flat 
REE patterns with high values of HREE, which is a relative significant enrichment similar to that reported in kaolin from Warren (Georgia, USA) from heavy, light and grit

317 fractions (Elliott et al. 2018). They also have a negative Sc anomaly as reported in heavy and grit mineral fractions from Warren kaolin too. Only sample L-1 from

Caluquembe has a different behaviour with and Sc enrichment as light fraction from Jeffersonville Member and Buffalo Creek in Georgia, USA.

DISCUSSION

\section{Classification of the Caluquembe deposit}

Considering the little available geological information about this area, it is necessary to establish a formal classification of the Caluquembe kaolin deposit using

The Chemical Index of Alteration $(\mathrm{CIA})$ is also a very suitable parameter to determine the weathering level of feldspars and the corresponding formation of kaolin by this process (Nesbitt and Young, 1984). CIA is expressed from 0 to 100 and it is calculated using the main compositional elements of kaolin: $\mathrm{Al}, \mathrm{Na}, \mathrm{K}$, and $\mathrm{Ca}$ $\left[\mathrm{ClA}=\mathrm{Al}_{2} \mathrm{O}_{3} /\left(\mathrm{Al}_{2} \mathrm{O}_{3}+\mathrm{Na}_{2} \mathrm{O}+\mathrm{K}_{2} \mathrm{O}+\mathrm{CaO}\right) \cdot 100\right]$. The $\mathrm{ClA}$ parameters of the Caluquembe 
kaolin have indexes from 82 to 95 (Table 3), which are significantly high and indicate an elevated level of feldspar alteration. In addition, it is possible to distinguish changes in the $\mathrm{CIA}$ parameter comparing kaolin samples obtained in the same outcrop from different depths in the profile. For instance, in sample KU6B (upper level) and sample KU6D (lower level), the CIA parameter is 87 and 82 respectively, indicating a significant 
kaolin deposits from the Caluquembe area should be regarded as strong evidence

363 indicating that they originated from the weathering of precursor granitic rocks.

364 Therefore, kaolin deposits from Caluquembe should be classified as primary type 365 kaolin deposits (Dill, 2016).

\section{Economic interest}

The potential extension of kaolin outcrops in Caluquembe is estimated around $20 \mathrm{~km}^{2}$, achieving a significant thickness that ranges from 5 to 10 meters (Figure 2). At present, a further evaluation is being carried out in the area to obtain a more accurate calculation of the extension and thickness of the kaolin deposits. However, the preliminary estimation concludes that potential inferred reserves of kaolin in the Caluquembe area are estimated around $500,000,000 \mathrm{~m}^{3}$. Although this calculation is approximate and more accurate studies are necessary, this preliminary volume would suggest that Caluquembe is a medium-size kaolin deposit, bigger than other deposits from Western Africa such as Makoro, Botswana (Ekosse, 2000). consequently considered as a significant parameter to determine kaolin quality. 379 Caluquembe $\mathrm{Al}_{2} \mathrm{O}_{3}$ contents (21.9 to 32.2 wt. \%) and $\mathrm{SiO}_{2} / \mathrm{Al}_{2} \mathrm{O}_{3}$ ratio (1.28) are similar to those reported for kaolin from the Zhanjiang, Longyan and Dazhou deposits 381 (Guangdong Province, China; Wilson et al., 1997), and slightly higher than the theoretical value for kaolinite (1.16). However, $\mathrm{Fe}_{2} \mathrm{O}_{3}$ contents of Caluquembe kaolin are quite significant (1.4 to $4.3 \mathrm{wt}$. \%) and they should be considered as penalizing for 
the potential marketing of the Caluquembe kaolin (Saikia et al., 2003, Lopez Galindo et al., 2007).

The mineralogical and chemical compositions of kaolin from Caluquembe are similar to other African kaolins. In addition, the kaolinite grade is slightly lower or similar to those found in Koutaba and Mayouom in Cameroon (Nkalih Mefire et al., 2015; Njoya et al., 2006), central Uganda (Nyakairu et al., 2001), Makoro in Botswana (Ekosse, 2000) and Grahamstown in South Africa (Heckroodt, 1991) (Table 5). The mineralogical composition of three classical kaolin deposits developed from precursor granites is presented for comparison in the Table 5: Guandong (China), Otovice (Czech Republic) and Cornwall (England.) All of them have higher kaolinite contents than the Caluquembe deposit.

Considering the main features of Caluquembe kaolin, the suitable application of this material should be focused on the fabrication of bricks, pavers, roofing tiles and

In addition, kaolin deposits have recently been considered non-conventional Ekosse, 2000; Nyakairu et al., 2001; Njoya et al., 2006; Ekosse, 2010 ; Nkalih Mefire et al., 2015). sources of critical metals such as REE (Aagaard, 1974; Laufer et al., 1984; Xiao et al., 2016; Sanematsu and Watanabe, 2016; Elliot et al., 2018). Values of $\sum$ REE (La, Ce, Pr, $\mathrm{Nd}, \mathrm{Sm}, \mathrm{Eu}, \mathrm{Gd}, \mathrm{Tb}, \mathrm{Dy}, \mathrm{Ho}, \mathrm{Er}, \mathrm{Tm}, \mathrm{Yb}, \mathrm{Lu})$ in Caluquembe are highly erratic 129.58 ppm to 563.5 ppm, Table 4 and do not show a correlation with $\mathrm{SiO}_{2}, \mathrm{Fe}_{2} \mathrm{O}_{3}, \mathrm{CaO}, \mathrm{P}_{2} \mathrm{O}_{5}$ and $\mathrm{MnO}$. Samples are more enriched in LREE (Table 4) and the ratio LREE/HREE is homogeneous by a mean factor $\sim 14$. A good positive correlation exists between $Y$ and REE $\left(R^{2}=0.98\right)$ and between $Y$ and HREE $\left(R^{2}=0.99\right)$. The correlation between REY and 
408 kaolinite wt. \% is positive $\left(R^{2}=0.75\right)$ except in sample $L-1$. A positive correlation is 409 shown between $Y$ and kaolinite wt. \% $\left(R^{2}=0.78\right)$ for except sample $L-1$. In some samples 410 from the Caluquembe area, the REY content is higher than $600 \mathrm{ppm}$ (Table 4), which is 411 higher than that reported in other deposits, for instance, in Uganda and Cameroon 412 (Table 4). Therefore, considering the medium size of the Caluquembe kaolin deposit 413 (Sanematsu and Watanabe, 2016) this can be considered as a potential non414 conventional source of REY. However, more detailed studies will be necessary to determine which mineral phases are enriched in REE and their relationship between subproduct during kaolinite exploitation.

The present work is the first study of the recently discovered kaolin deposit from the Caluquembe area (Angola). The studied kaolin samples do not have significant compositional and mineralogical differences. Kaolinite contents calculated from full profile refinement by XRPD range between 50.4 and 87.0 wt. \% and between 44.3 and 92.9 wt. \%, calculated with TGA (Figure 8). The samples that outcrop in shallower areas are richer in kaolinite than deeper samples. A relevant conclusion of the present work is that full profile 427 fitting by XRPD and TGA results have a good correlation, and the combination of both techniques is suitable to determine kaolinite contents in this type of clay deposits. Mineralogy and compositional features of kaolin samples indicate that 430 Caluquembe deposits were generated by weathering of granitic rocks and the 
corresponding alteration of feldspars. Therefore, they should be classified as primary kaolin deposits.

The economic importance of these deposits is considered to be very relevant, especially considering that they are located in an underdeveloped region. The mineralogical and compositional features of the Caluquembe kaolin and its low to medium crystallinity indicate that the most suitable application for this clay is the manufacture of structural products, such as bricks, pavers and roofing tiles. Caluquembe kaolin would need to be refined and processed to be used in other cosmetics.

The chondrite-normalized rare earth element (REE) patterns show enrichment a sub product in a possible future kaolinite exploitation is highly recommended. very suitable for the exploration and potential exploitation of kaolinite, a very valuable raw material with a bright future.

\section{ACKNOWLEDGMENTS}

This research was supported by the CGL2012-36263, CGL2006-12973 and

452 CGL2009-13758 projects of the Ministerio de Ciencia e Innovación of the Spanish 
by a FI grant to J. Xu (coded FI_B 00904) sponsored by the Secretaria d'Universitats $i$ Recerca of the Departament d'Economia $i$ Coneixement of the Generalitat de Catalunya. The authors thank the Scientific and Technical Centers of the University of Barcelona (CCITUB) for their support in carrying out experimental analyses.

\section{REFERENCES}

Aagaard, P. (1974) Rare earth elements adsorption on clay minerals. Bulletin du groupe français des argiles, 26, 193-199.

Aparicio, P. and Galan, E. (1999) Mineralogical interference on kaolinite crystallinity index measurements. Clays and Clay Minerals, 47, 12-27.

Aparicio, P., Galan, E. and Ferrell, R.E. (2006) A new kaolinite order index based on XRD profile fitting. Clay Minerals, 41, 811-817.

Ashwal, L.D., Twist, D. (1994) The Kunene complex, Angola/Namibia: a composite massif-type anorthosite complex. Geological Magazine, 131, 579-591.

Bailey, S.W. (1980) Structure of layer silicates. Pp. 1-123 in: Crystal structure of Clay Minerals and their X-ray Identification (G.W. Brindley and G. Brown, editors). Monograph, 5. Mineralogical Society, London.

Bao, Z. and Zhao, Z. (2008) Geochemistry of mineralization with exchangeable REY in the weathering crusts of granitic rocks in South China. Ore Geology Reviews, 13, 519-535.

Bish, D.L. (1993) Rietveld refinement of the kaolinite structure at $1.5 \mathrm{~K}$. Clays and Clay Minerals, 41, 738-744.

Bermúdez-Lugo, O. (2014) Angola and Namibia, Minerals years book. U.S. Geological Survey. 
477 De Carvalho, H., Tassinari, C., Alves, P., Guimaraes, F., Simoes, M.C. (2000) 478 Geochronological review of the Precambrian in western Angola: Lings with Brazil. 479 Journal of African Earth Sciences, 31, 383-402.

480 Detellier, C. and Schoonheydt, R.A. (2014) From Platy Kaolinite to Nanorolls. Elements, $481 \quad 10,201-206$.

482

Dedzo, G.K. and Detellier, C. (2016) Functional nanohybrid materials derived from 483 kaolinite. Applied Clay Science, 130, 33-39.

Dill, H. G. (2016) Kaolin: Soil, rock and ore. From the mineral to the magmatic, sedimentary and metamorphic environments. Earth-Science Reviews, 161, 16-129.

Ekosse, G-I (2000) The Makoro kaolin deposit, southeastern Botswana: its genesis and possible industrial applications. Applied clay science, 16, 301-320.

Ekosse, G-I. (2010) Kaolin deposits and occurrences in Africa: Geology, mineralogy and utilization. Applied Clay Science, 50, 212-236.

Elliot. W.C., Gardner, D.J., Malla, P., Riley, E. (2018) A New Look at the Occurrences of the Rare-Earth Elements in the Georgia Kaolins. Clays and Clay Minerals, 66 (3), 245260.

Flanagan, M.D. (2016) Clays in Mineral Commodity summaries. U.S. Geological Survey, 50.

Galán, E. (2006) Genesis of clay minerals Pp 1129-1162 in Handbook of clay science. (Bergaya, F.; Theng, B.K.G. and Lagaly, G. editors) Developments in clay science 1. Elsevier.

Galán, E., Aparicio, P., Fernández-Caliani, J.C., Miras, A., G.Márquez, M, Fallick, A. and Clauer, N. (2016) New insights on mineralogy and genesis of kaolin deposits:The Burela kaolin deposit (Northwestern Spain). Applied Clay Science, 131, 14-26. 
501 Gomes, C., Velho, J.A. and Guimaraes F. (1994) Kaolin deposit of Mevaiela (Angola) alteration product of anorthosite: assessment of kaolin potentialities for 503 applications in paper. Applied Clay Science, 9, 97-106.

Guggenheim, S., Adams, J.M., Bain, D.C., Bergaya, F., Brigatti, M.F., Drits, V.A., 505 Formoso, M.L.L., Galán, E., Kogure, T. and Stanjek, H. (2006) Summary of 506 recommendations of nomenclature committees relevant to clay mineralogy: report 507 of the Association Internationale pour l'etude des Argiles, nomenclature committee 508 for 2006. Clay Minerals, 41, 863-877.

Hanson, R.E. (2003) Proterozoic geochronology and tectonic evolution of southern

Heckroodt, R.O. (1991) Clay and clay materials in South Africa. Journal of the south African institute of mining and metallurgy, 91, 343-363.

Hinckley, D.N. (1963) Variability in "crystallinity" values among the kaolin deposits of the coastal plain of Georgia and South Carolina. Clays and Clay Minerals, 11, 229235.

Jelsma, H., Perrit, S.H., Armstrong, R.A., Ferreira, H.F. (2011) SHRIMP U-Pb zircon geochronology of basement rocks of the Angolan Shield, western Angola. In: Proceedings of the $23^{\text {rd }}$ CAG, Johannesburg. Council for Geoscience, Pretoria 203.

Kadir, S. and Kart, F. (2009) The occurrence and origin of the Sögüt kaolinite deposits in the Paleozoic Saricayaka granite-granodiorite complexes and overlying Neogene sediments (Bilecik, northwestern Turkey). Clays and clay Minerals, 57, 311-329. 
Laufer, F., Yariv, S. and Steinberg, M. (1984) The adsorption of quadrivalent cerium by kaolinite. Clay Minerals, 19, 137-149.

526

Liu, X., Liu*, X. and Hu, Y. (2015) Investigation of the thermal behaviour and decomposition kinetics of kaolinite. Clay Minerals, 50, 199-209

López-Galindo, A., Viseras, C. and Cerezo, P. (2007) compositional, technical and safety specifications of clays to be used as pharmaceutical and cosmetic products. Applied Clay Science, 36, 51-63.

MacKenzie, R.C. (1957) The Differential Thermal Investigation of Clays. Mineralogical Society (Clay Minerals Group), London, 456 pp.

Mansa, R., Ngassa Piegang, G. B. and Detellier, C. (2017) Kaolinite aggregation in booklike structures from non-aqueous media. Clays and Clay Minerals, 65, 193-205.

Marques, M. M. (1977) Esboço das grandes unidades geomorfológicas de Angola (2ª aproximação). Instituto de Investigaçao Cientifica Tropical, Garcia de Orta, Sérvicio Geologico, Lisboa, 2(1), 41-43.

Mayer, A., Hofmann, A.W., Sinigoi, S., Morais, E. (2004) Mesoproterozoic Sm-Nd and $\mathrm{U}-\mathrm{Pb}$ ages for the Kunene Anorthosite Complex of SW Angola. Precambrian Research, 133, 187-206.

McCourt, S., Armstrong, R.A., Jelsma, H., Mapeo, R.B.M. (2013) New U-Pb SHRIMP ages from the Lubango region, SW Angola: insights into the Palaeoproterozoic evolution of the Angolan Shield, southern Congo Craton, Africa. Journal of the Geological Society of London, 170, 353-363.

McDonough, W.F. and Sun, S.S. (1995) The composition of the earth. Chemical Geology, 120, 223-225. 
547 Montenegro de Andrade, M. (1954) Rochas graníticas de Angola. Memórias, série 548 geológica IV. Ministério do Ultramar, 464 pp.

549 Moore, D.M. and Reynolds, R.C.Jr. (1997) X-Ray Diffraction and the Identification and $550 \quad$ Analysis of Clay Minerals. Oxford University Press, 332 pp.

551 Murray, H.H. (1999c) Applied clay mineralogy today and tomorrow. Clay Minerals, 34, $552 \quad 39-49$.

553 Murray, H.H. (2000) Traditional and new applications for kaolin, smectite, palygorskite: 554 a general overview. Applied Caly Science, 17, 207-221.

Nesbitt, H.W. and Young, G.M. (1984) Prediction of some weathering trends of plutonic and volcanic rocks based on thermodynamic and kinetic considerations.

Nkalih Mefire, A., Njoya, A., Yongue Fouateu, R., Mache, J. R., Tapon, N.A., Nzeukou Nzeugang, A., Melo Chinje, U., Pilate, P., Flament, P., Siniapkine, S., Ngono, A. and Fagel, N. (2015) Occurrences of kaolin in Koutaba (west Cameroon): Mineralogical and physicochemical characterization for use in ceramic products. Clay Minerals, 50, 593-606.

Nguie, G., Dedzo, G.K. and Detellier, C. (2016) Synthesis and catalytic application of palladium nanoparticles supported on kaolinite-based nanohybrid materials. Dalton Transactions, 45.

Njoya, A., Nkoumbou, C., Grosbois, C., Njopwouo, D., Njoya, D., Courtin-Nomade, A., Yvon, J. and Martin, F. (2006) Genesis of Mayouom kaolin deposit (western Cameroon). Applied Clay Science, 32, 125-140. 
Nyakairu, G. W. A. and Koeberl, C. (2001) Mineralogical and chemical composition and distribution of rare earth elements in clay-rich sediments from central Uganda. Geochemical Journal, 35, 13-28.

Nyakairu, G. W. A., Koeberl, C. and Kurzweil, H. (2001) The Buwambo kaolin deposit in central Uganda: Mineralogical and chemical composition. NOTE, Geochemical Journal, 35, 245-256.

Petschick, R. (2004) MacDiff 4.2.5. http://servermac.geologie.unifrankfurt.de/Rainer.html.

Phipps, J.S. (2014) Engineering minerals for performance applications: an industrial perspective .Clay Minerals, 49, 1-16

Pruett, R.J. (2016) Kaolin deposits and their uses: Northern Brazil and Georgia, USA. Applied Clay Science, 131, 3-13.

Rudnick, R.L. and Gao, R. (2003) Composition of the continental crust. Pp. 1-64 in: The Crust (R.L. Rudnick, editor). Treatise of Geochemistry, 3. Elsevier-Pergamon, Oxford, UK.

Saikia, N., Bharali, D., Sengupta, P., Bordolo, D., Goswamee, R., Saikia, P. and Borthakur P.C. (2003) Characterization, beneficiation and utilization of a kaolinite clay from Assam, India. Applied Clay Science, 24, 93-103.

Sanematsu, K. and Watanabe, Y. (2016) Characteristics and Genesis of Ion AdsorptioType Rare Earth Element Deposits. Reviews in Economic Geology, 18, 55-79.

Savianno, G., Violo, M., Pieruccini, U., lopes da Silva, E.T. (2005) Kaolin deposits from the northern sector of the Cunene Anorthosite Complex (southern Angola). Clays and Clay Minerals, 53, 674-685. 
Schroeder, P.A. and Erickson, G. (2014) Kaolin: From Ancient Porcelains to Nanocomposites. Elements, 10, 177-182.

Silva M.V.S., 1973b. Carta Geologica de Angola. Folha N 207 Gungo. Scale 1:100 000.

Silva, A.T.S.F. and Simões, M.V.C. (1980/1981) Geologia da região de Caluquembe (Angola), Livro de Homenagem ao Professor Doutor Carlos Teixeira pela sua jubilação, Bol. Soc. Geol. Portugal, 22, 363-375.

Stoch L. (1974) Mineraly Ilaste ('Clay Minerals'). Geological Publishers, Warsaw, 186193.

Taylor, S.R. and McLennan, S.H. (1995) The geochemical evolution of the continental crust. Reviews of Geophysics, 33, 241-265.

TOPAS (2009) General Profile and Structure Analysis Software for Powder Diffraction Data, version 4.2, Bruker AXS Gmbh, Karlsruhe, Germany, 2009.

Thorez, J. (1975) Phyllosilicates and clay minerals. A laboratory handbook for their Xray diffraction analysis. Lelotte (Disno), France, 580 pp.

Wilson J.R., Halls, C. and Spiro, B. (1997) A comparison between the China clay deposits of China and Corwall. Proceedings of the Usher Society, 9, 195-200.

Xiao, Y., Huang, L., Long, Z.,Feng, Z. and Wang, L. (2016) Adsorption ability of rare earth elements on clay minerals and its practical performance. Journal of rare earths, 34, $5,543-548$

Young, R.A. and Hewat, A.W. (1988) Verification of the triclinic crystal structure of kaolinite. Clays and Clay Minerals, 36, 225-232. 
616 Figure 1. (a) Simplified geological map of Angola (Silva, 1973b); (b) Geological map the 617 Caluquembe region and location of the studied samples.

618 Figure 2. Views of kaolin outcrops from the Caluquembe area: (a) Plain areas with 619 typical surface alteration due to significant iron contents; (b), (c) and (d) kaolinite 620 outcrops in rivers and creeks of the Caluquembe area.

Figure 3. Backscattered electron images (SEM-BSE) of sample Q-2: (a) quartz (Qtz) and feldspars (Fsp) settled in a finer-grained mass consisting of kaolinite (KIn) and muscovite; (b) Intergrowths of kaolinite (KIn) and muscovite (Ms) scattered in a groundmass comprised of kaolinite; (c) Muscovite (Ms) layers separated along cleavage surfaces; (d) REE phosphate and K-feldspars (Fsp) in a groundmass made up of kaolinite (KIn) forming booklets that are often radial.

Figure 4. (a) XRPD profile refinement (by Topas V4.2 software) of sample KL13-2. The red line corresponds to the calculated profile while the blue line corresponds to the experimental profile. The Bragg positions of mineral phases are shown at the bottom, Rwp $=8.7$ (agreement with weighted profile factor in the Rietveld method); (b) XRPD profile refinement of sample $\mathrm{KC} 12$ in the region $170-30$ - $2 \theta$. The blue thick line corresponds to the experimental XRD profile of this sample. The green line corresponds to the calculated XRD profile of kaolinite and d-spacing for 020 reflection for kaolinite is $4.4719 \AA$, for $1 \overline{1} 0$ is $4.3649 \AA$ and for $11 \overline{1}$ is $4.1803 \AA$. The blue and purple lines correspond to calculated XRD profiles of quartz and muscovite, respectively, also included the calculated XRD profiles of hematite, albite low and microcline, $R w p=14.1$; 
637 (c) XRPD profile refinement of sample KA in the region 17--30 $2 \theta$. The blue thick line

638

639

640

641

642

643

644

645

646

647

648

649

650

651

652

653

654

655 corresponds to the experimental XRD profile of this sample. The green line corresponds to calculated XRD profile of kaolinite. The $d$-spacing for 020 reflection of kaolinite is $4.4694 \AA$, for $1 \overline{1} 0$ is $4.3628 \AA$ and for $11 \overline{1}$ is $4.1795 \AA$. The blue and purple lines correspond to calculated XRD profile of quartz and muscovite, respectively, also included the calculated XRD profiles of hematite, albite low and microcline, Rwp=11.3.

Figure 5. Relation between muscovite+K-feldspar vs. kaolinite (wt. \%) calculated by XRPD profile refinement with Topas V4.2.

Figure 6. XRPD of samples in the region from $4^{\circ}$ to $15^{\circ} 2 \theta$ : (a) KL13-2, muscovite and kaolinite; (b) KL6E muscovite, kaolinite, and smectite; (c) KK8, muscovite, kaolinite, and illite.

Figure 7. DTA-TGA curves of kaolin from Calumquembe of sample KL13-2. DTA (black line) - TGA (gray line).

Figure 8. Kaolinite content (wt. \%) calculated by XRPD with Topas V4.2 vs. kaolinite content (wt. \%) calculated by mass loss in TGA.

Figure 9. The enrichment/depletions of REE of Caluquembe kaolin samples: a) Results normalized to C1 chondrite (McDonough and Sun, 1995); b) Results normalized to UCC (Rudnick and Gao, 2003).

\section{TABLES}


656

657

658

659

660

661

662

663

664

665

666

667

668

669

670

671

672

673
Table 1. Mineral content (wt. \%) calculated by XRPD profile refinement with Topas V4.2. Temperature of dehydration ( $\mathrm{Tm}$ ) of kaolinite, mass loss and kaolinite content (wt. \%) calculated by TGA.

Table 2. Mineral content (wt. \%) calculated by XRPD profile refinement with Topas V4.2 in samples with smectite and illite. Temperature of dehydration (Tm) of kaolinite, mass loss and kaolinite content (wt. \%) calculated by TGA.

Table 3. Major elements composition of kaolin samples (wt.\%) from Caluquembe, Angola; sample BW-1 from Buwambo, and MG-1 from Migade, Uganda (Nyakairu et al., 2001); sample MY03 from Mayouom, Cameroon (Njoya et al., 2006); granite from Sa Bandeira, Angola (Montenegro de Andrade, 1954).

Table 4. Trace and REE elements (ppm) of samples from Caluquembe, Angola; sample BW-1 from Buwambo, and MG-1 from Migade, Uganda (Nyakairu et al., 2001); sample MY03 from Mayouom, Cameroon (Njoya et al., 2006). n.d =not detected, $<$ dl $=<$ to detection limits

Table 5. Mineralogical composition determined by XRPD (wt.\%) of different kaolin deposits from Africa (Angola, Cameroon, Uganda, South Africa, Botswana) and worldwide (China, Czech Republic and England). 


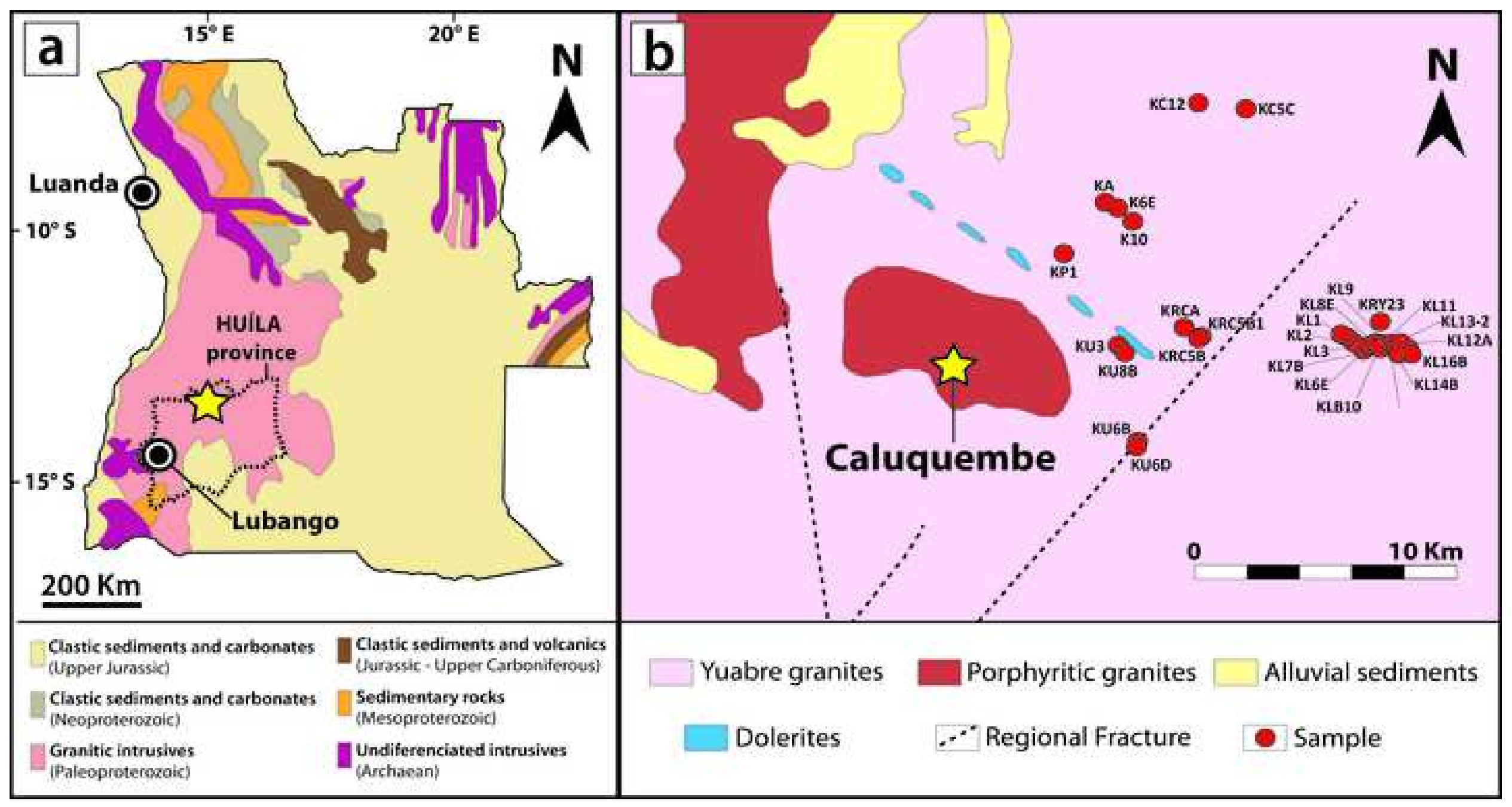



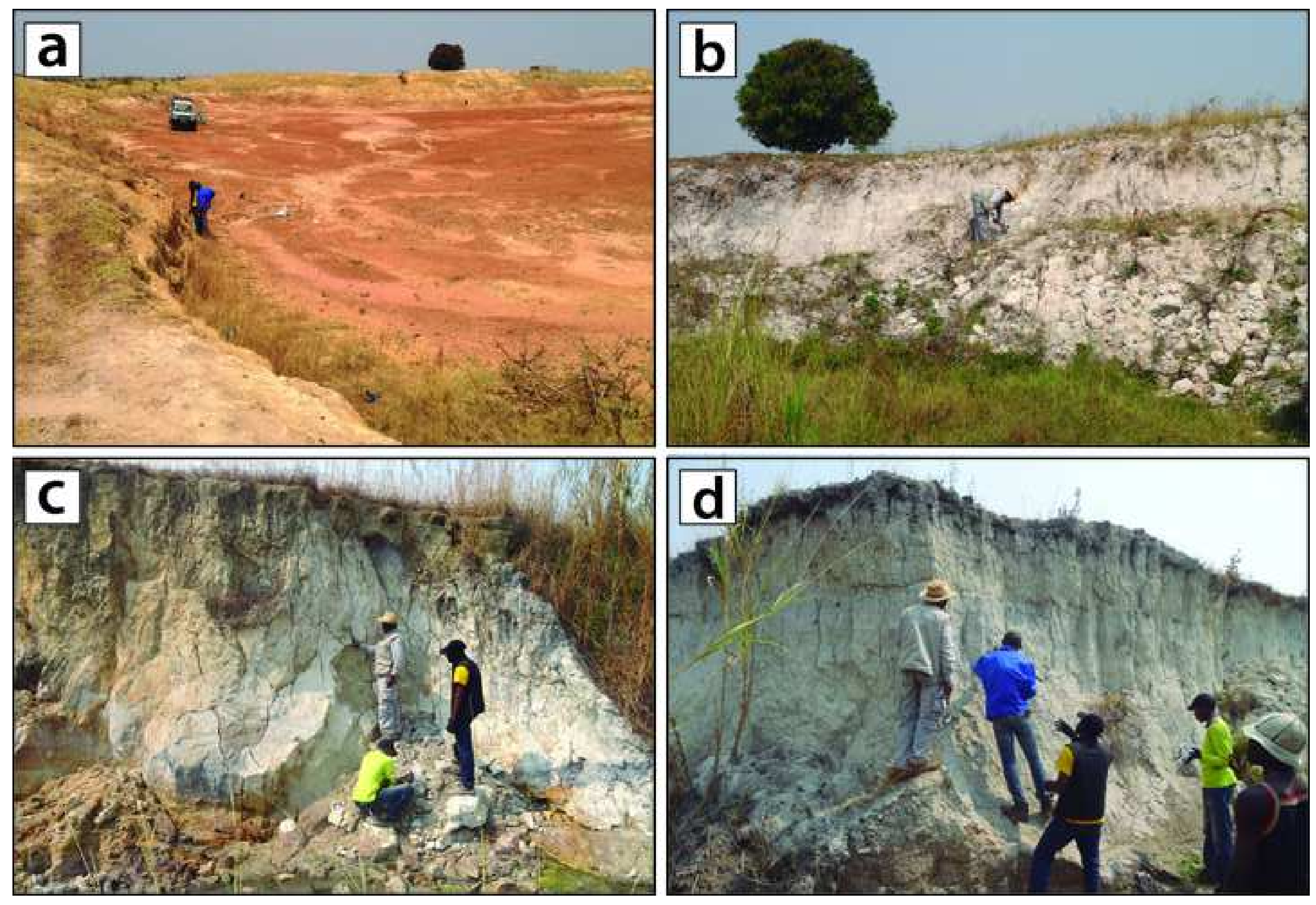


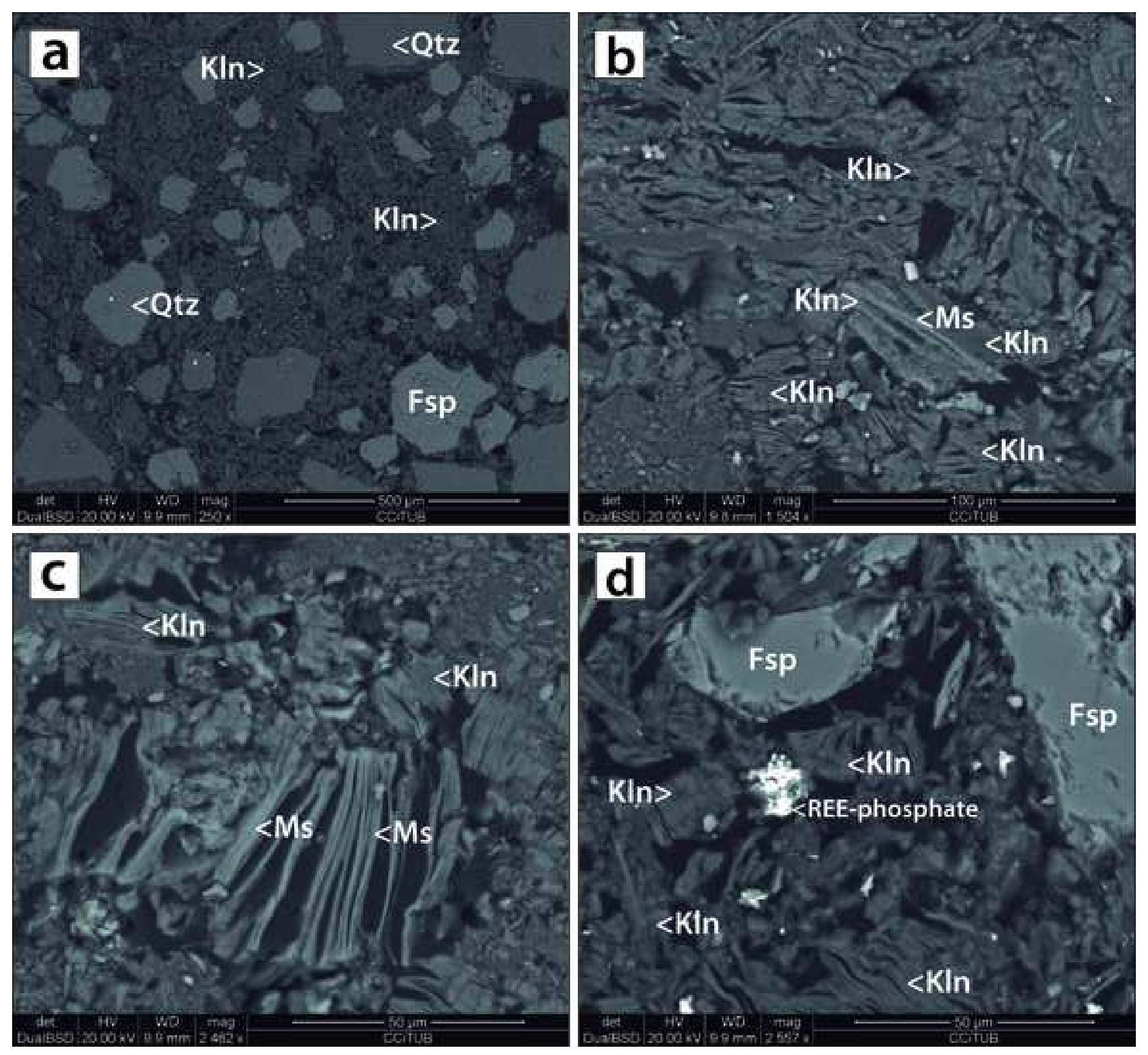



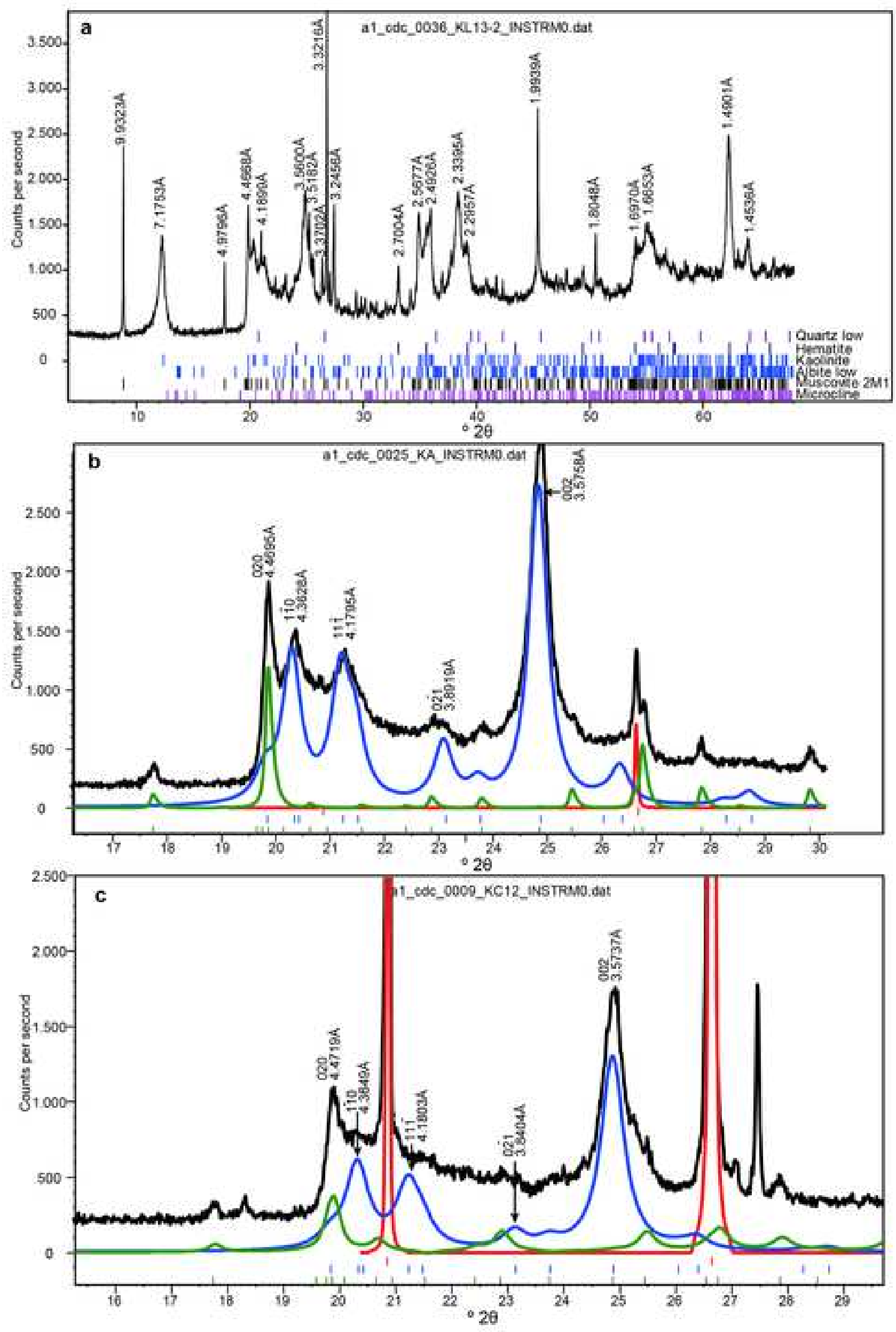


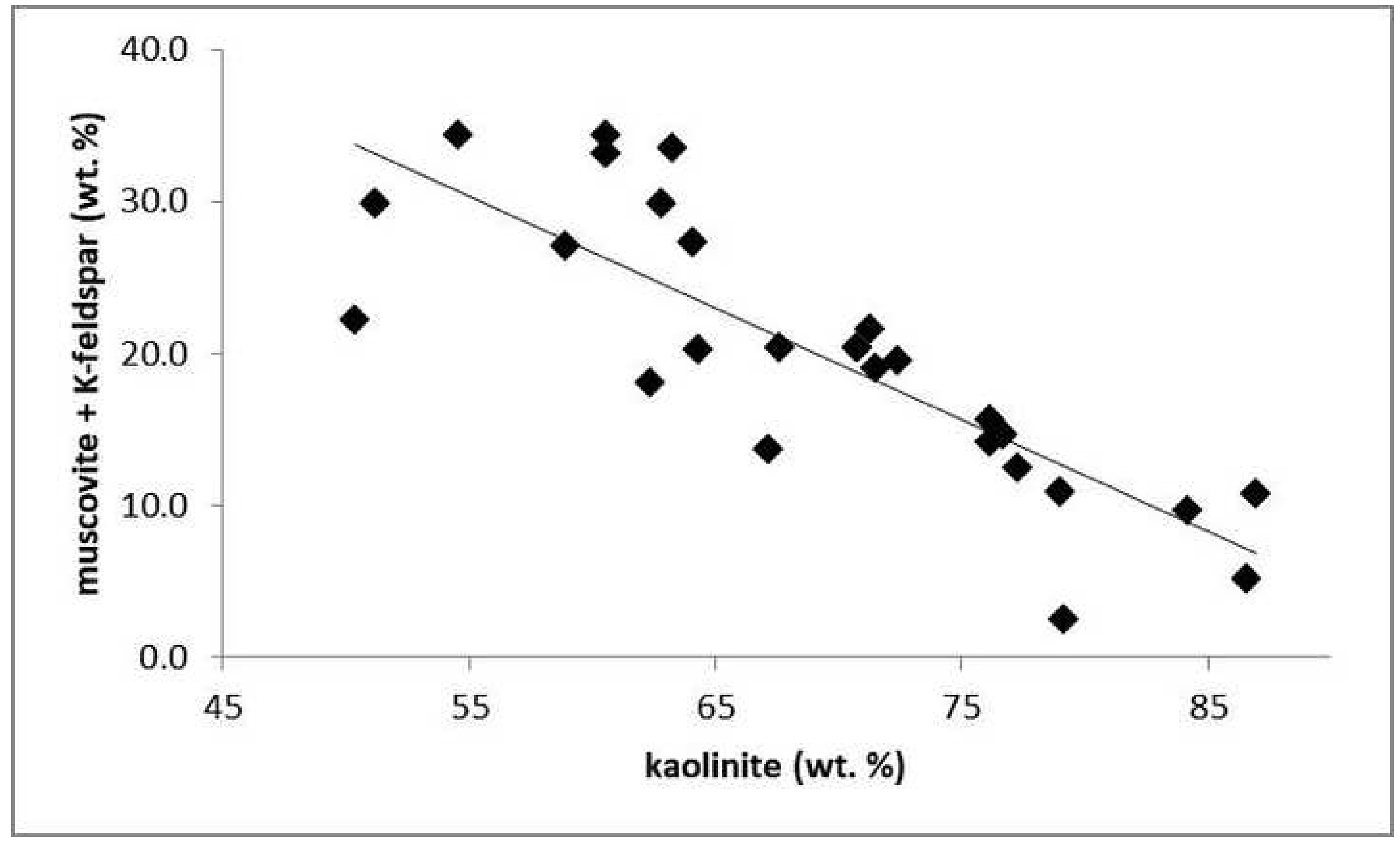




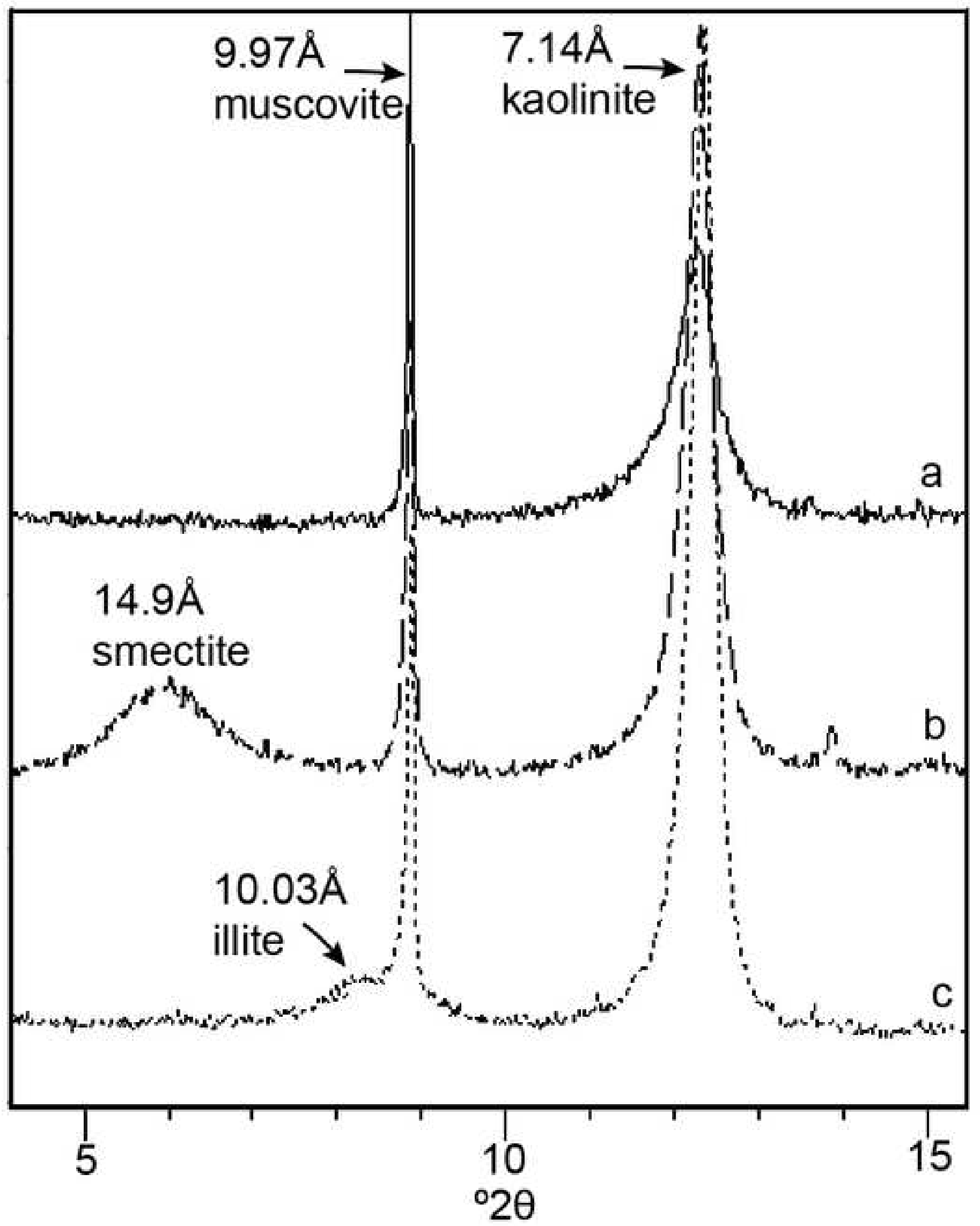




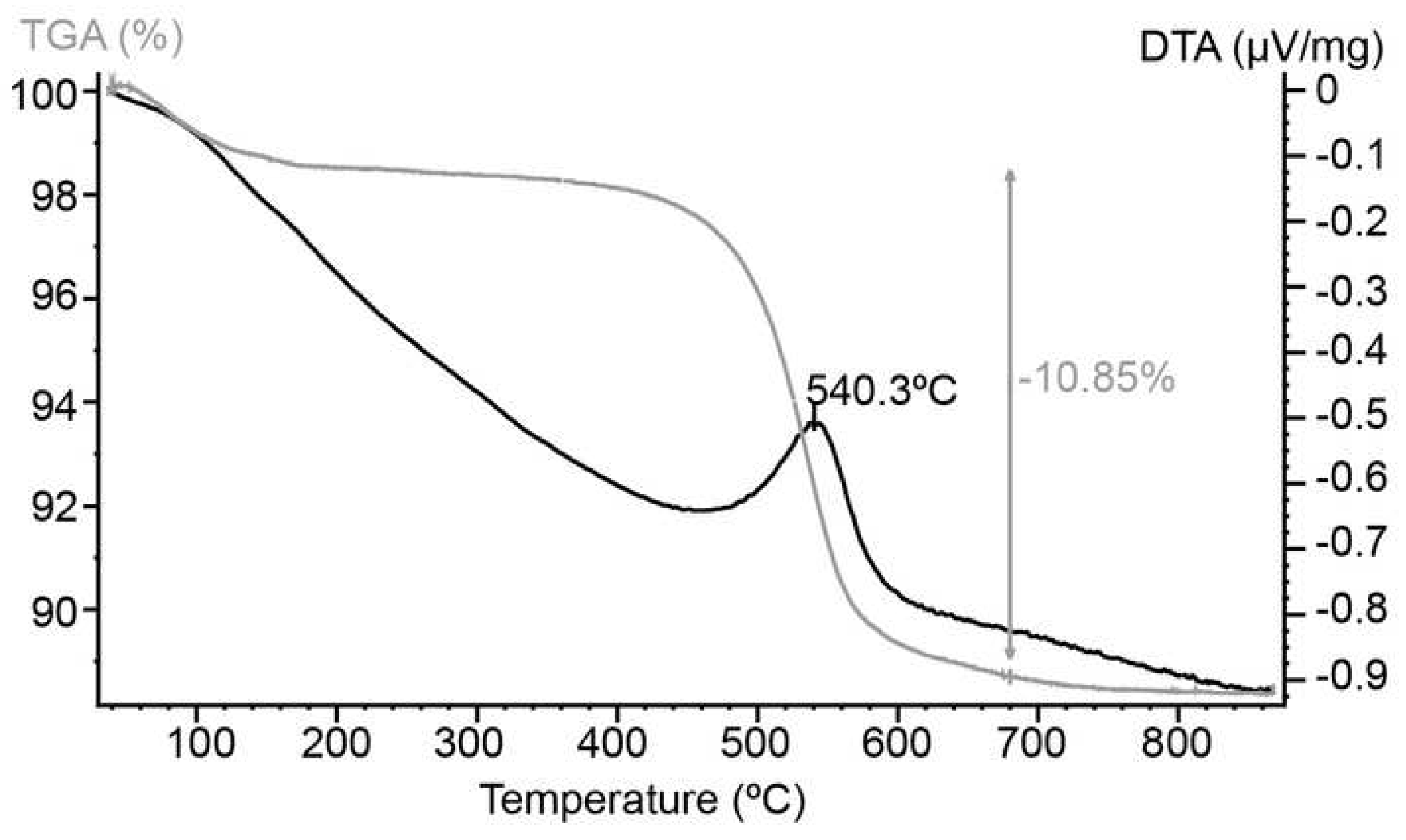




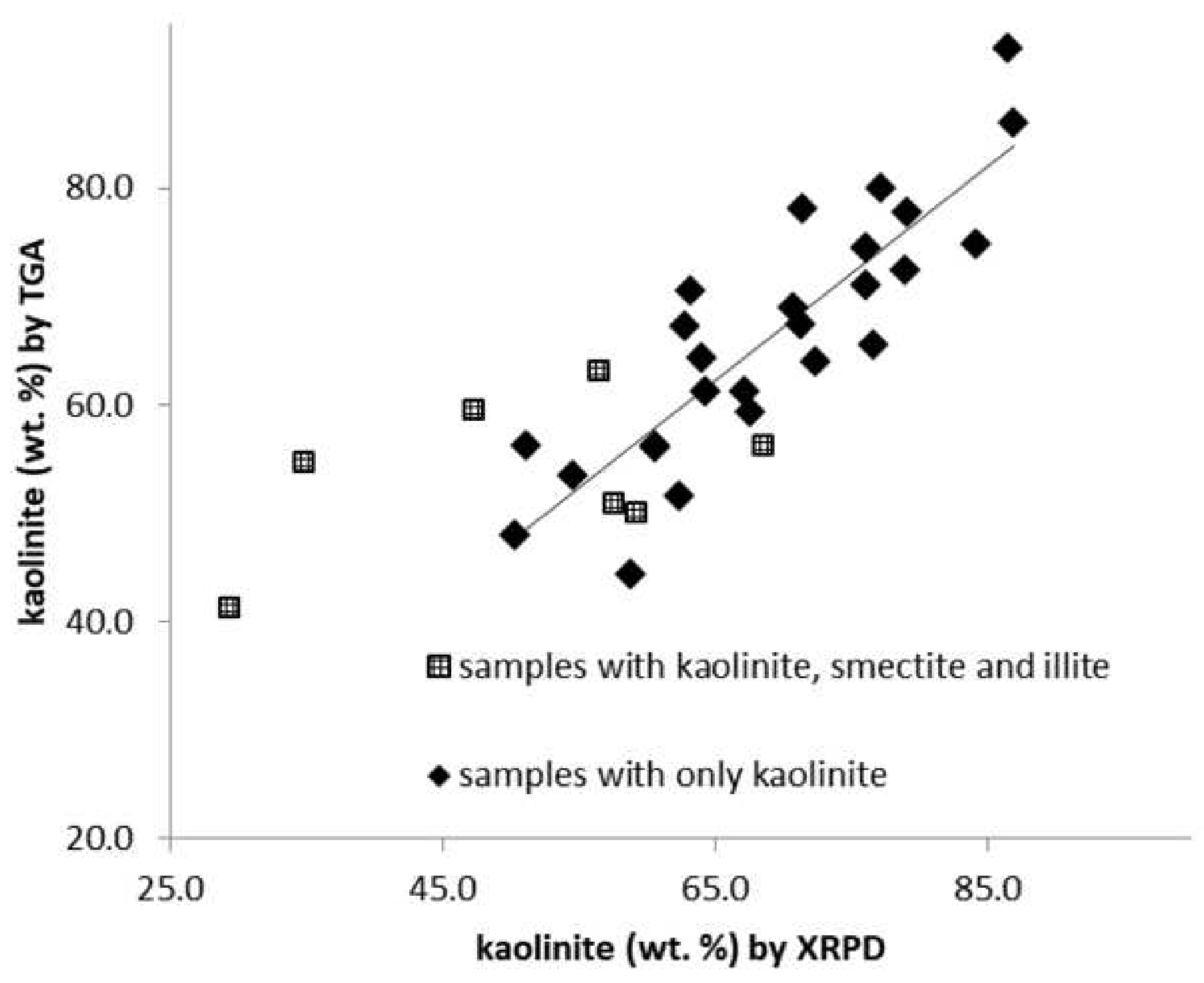




\begin{tabular}{|c|c|c|c|c|c|c|}
\hline \multirow[b]{2}{*}{ Sample } & \multicolumn{6}{|c|}{ Full profile refinement XRPD (wt. \%) } \\
\hline & kaolinite & muscovite & quartz & plagioclase & microcline & hematite \\
\hline $\mathrm{KA}$ & 87 & 8.6 & 0.3 & 2 & 2.1 & 0.02 \\
\hline $\mathrm{K} 6 \mathrm{E}$ & 67.2 & 10.7 & 13.1 & 5.9 & 3 & 0.06 \\
\hline K10 & 64.3 & 17 & 10.1 & 5.3 & 3.2 & 0.05 \\
\hline KP1 & 70.8 & 8.5 & 2.8 & 1.97 & 11.9 & 1.6 \\
\hline KC12 & 50.4 & 21.3 & 23.5 & 3.8 & 0.9 & 0.07 \\
\hline KC5 C & 51.2 & 27.3 & 11.5 & 7.4 & 2.6 & 0.04 \\
\hline KU3 & 79.2 & 1.1 & 14.8 & 2.9 & 1.4 & 0.58 \\
\hline KU6B & 71.5 & 3.9 & 7.7 & 1.8 & 15.1 & 0 \\
\hline KU6D & 58.9 & 5.5 & 10.5 & 3.6 & 21.5 & 0.04 \\
\hline KU8B & 54.6 & 24.6 & 8.8 & 2.1 & 9.8 & 0.07 \\
\hline KRC3B & 63.3 & 21.4 & 2.9 & 0.3 & 12.1 & 0.03 \\
\hline KRC5B & 62.8 & 23.9 & 3.5 & 3.9 & 5.9 & 0.04 \\
\hline KRC5B1 & 64.1 & 20.8 & 4 & 4.6 & 6.5 & 0.03 \\
\hline KRY23 & 76.7 & 9.9 & 7.7 & 0.9 & 4.8 & 0.03 \\
\hline $\mathrm{KRCA}$ & 77.3 & 8.4 & 5.7 & 4.5 & 4.1 & 0.04 \\
\hline KK14C & 60.6 & 29.2 & 4.3 & 0.3 & 5.1 & 0.5 \\
\hline KKL13B & 71.3 & 17.2 & 5.3 & 1.7 & 4.4 & 0.06 \\
\hline KKL17B & 76.2 & 11.5 & 4.2 & 4 & 4.1 & 0.04 \\
\hline KL9 & 62.4 & 12.4 & 15.1 & 4.3 & 5.7 & 0.11 \\
\hline KL11 & 67.6 & 14.9 & 10.2 & 1.7 & 5.5 & 0.06 \\
\hline $\mathrm{KL} 12 \mathrm{~A}$ & 76.2 & 11.2 & 4.8 & 4.7 & 3 & 0.06 \\
\hline KL13-2 & 84.2 & 2.9 & 0 & 5.7 & 6.7 & 0.5 \\
\hline KL14B & 60.6 & 26 & 5.1 & 1.2 & 7.1 & 0.02 \\
\hline KL16B & 72.4 & 15.4 & 5.3 & 2.6 & 4.1 & 0.2 \\
\hline $\mathrm{L}-1$ & 86.6 & 3.9 & 1.9 & 6.3 & 1.2 & 0.1 \\
\hline L-2 & 79 & 7.3 & 6.9 & 3.2 & 3.6 & 0.01 \\
\hline
\end{tabular}




\begin{tabular}{|c|c|c|}
\hline $\operatorname{Tm}\left({ }^{\circ} \mathrm{C}\right)$ & $\begin{array}{c}\text { TGA } \\
\text { Mass loss } \\
\text { (wt.\%) }\end{array}$ & $\begin{array}{c}\text { kaolinite } \\
\text { (wt. \%) }\end{array}$ \\
\hline 550.3 & 12.0 & 85.9 \\
\hline 531.0 & 8.6 & 61.1 \\
\hline 529.3 & 8.6 & 61.1 \\
\hline 539.1 & 9.7 & 68.9 \\
\hline 518.7 & 6.7 & 47.9 \\
\hline 530.4 & 7.9 & 56.2 \\
\hline 526.6 & 10.9 & 77.6 \\
\hline 531.4 & 10.9 & 78.0 \\
\hline 520.0 & 6.2 & 44.3 \\
\hline 530.1 & 7.5 & 53.4 \\
\hline 542.4 & 9.9 & 70.4 \\
\hline 540.8 & 9.4 & 67.2 \\
\hline 541.0 & 9.0 & 64.3 \\
\hline 532.3 & 9.2 & 65.5 \\
\hline 546.0 & 11.2 & 80.0 \\
\hline 528.3 & 7.9 & 56.2 \\
\hline 534.2 & 9.4 & 67.4 \\
\hline 541.8 & 10.4 & 74.4 \\
\hline 525.4 & 7.2 & 51.5 \\
\hline 537.6 & 8.3 & 59.2 \\
\hline 536.0 & 10.0 & 71.0 \\
\hline 540.3 & 10.5 & 74.8 \\
\hline 541.6 & 7.8 & 56.0 \\
\hline 537.2 & 9.0 & 64.0 \\
\hline 527.9 & 13.0 & 92.9 \\
\hline 518.4 & 10.1 & 72.4 \\
\hline
\end{tabular}




\section{Full profile refinement XRPD (wt.\%)}

\begin{tabular}{lcccccc}
\multicolumn{1}{c}{ Sample } & kaolinite & muscovite & illite & smectite & quartz & plagioclase \\
\hline KK8 & 54 & 12 & 15 & & 9 & 4 \\
KK11A & 57.6 & & 8.1 & & 5.7 & 2.1 \\
KK13 & 59.3 & & 7.4 & & 9.6 & 2.8 \\
KL6E & 29.4 & 30.6 & & 16.7 & 5.5 & 11.5 \\
KL7B & 56.5 & 9.9 & 18.4 & & 3.8 & 4.8 \\
KL8E* & 34.8 & 23.8 & & 15.8 & 4.8 & 6.0 \\
KLB10 & 47.4 & 24.0 & & 10.1 & 5.5 & 4.0 \\
L-3 & 68.6 & 2.7 & 22.1 & & 3.9 & 2.0 \\
\hline
\end{tabular}




\begin{tabular}{ccccc}
\hline microcline & hematite & $\operatorname{Tm~(ㅇ)~}$ & $\begin{array}{c}\text { TGA } \\
\text { Mass loss } \\
\text { (wt.\%) }\end{array}$ & $\begin{array}{c}\text { kaolinite } \\
\text { (wt.\%) }\end{array}$ \\
\hline 6 & 0 & 520.1 & 7.7 & 54.8 \\
3.6 & 0.0 & 531.6 & 7.1 & 50.9 \\
8.0 & 0.2 & 528.3 & 7.0 & 50.0 \\
6.3 & 0.0 & 525.9 & 5.8 & 41.2 \\
6.5 & 0.0 & 535.0 & 8.8 & 63.1 \\
14.5 & 0.4 & 537.7 & 7.6 & 54.6 \\
9.0 & 0.1 & 530.8 & 8.3 & 59.5 \\
0.6 & 0.0 & 521.9 & 7.9 & 56.2 \\
\hline
\end{tabular}




\begin{tabular}{lccccc}
\hline Major elements & $\begin{array}{c}\text { Caluquembe } \\
\text { Angola } \\
\text { KU6B }\end{array}$ & $\begin{array}{c}\text { Caluquembe } \\
\text { Angola } \\
\text { KU6D }\end{array}$ & $\begin{array}{c}\text { Caluquembe } \\
\text { Angola } \\
\text { KL13-2 }\end{array}$ & $\begin{array}{c}\text { Caluquembe } \\
\text { Angola } \\
\text { K 6E }\end{array}$ & $\begin{array}{c}\text { Caluquembe } \\
\text { Angola } \\
\text { KLB 10 }\end{array}$ \\
\hline $\mathrm{SiO}_{2}$ & 53.10 & 63.24 & 45.35 & 56.08 & 51.57 \\
$\mathrm{Al}_{2} \mathrm{O}_{3}$ & 27.72 & 21.89 & 31.79 & 26.60 & 27.07 \\
$\mathrm{TiO}_{2}$ & 0.57 & 0.49 & 0.86 & 0.79 & 0.69 \\
$\mathrm{Fe}_{2} \mathrm{O}_{3}(\mathrm{~T})$ & 3.58 & 1.54 & 4.15 & 1.36 & 4.25 \\
$\mathrm{MnO}$ & 0.02 & 0.01 & 0.18 & 0.01 & 0.02 \\
$\mathrm{MgO}$ & 0.52 & 0.31 & 0.50 & 0.17 & 0.80 \\
$\mathrm{CaO}$ & 0.13 & 0.15 & 0.18 & 0.09 & 0.08 \\
$\mathrm{Na}_{2} \mathrm{O}$ & 0.07 & 0.14 & 0.03 & 0.01 & 0.04 \\
$\mathrm{~K}_{2} \mathrm{O}$ & 3.55 & 4.03 & 2.02 & 1.16 & 3.63 \\
$\mathrm{P}_{2} \mathrm{O}_{5}$ & 0.04 & 0.03 & 0.01 & 0.08 & 0.03 \\
$\mathrm{LOI}$ & 10.55 & 7.80 & 13.69 & 12.71 & 10.98 \\
$\mathrm{Total}$ & 99.84 & 99.64 & 98.74 & 99.07 & 99.17 \\
$\mathrm{ClA}$ & 87 & 82 & 93 & 95 & 87 \\
\hline
\end{tabular}




\begin{tabular}{ccccc}
\hline $\begin{array}{c}\text { Caluquembe } \\
\text { Angola } \\
\text { L1 }\end{array}$ & $\begin{array}{c}\text { Buwambo } \\
\text { Uganda } \\
\text { BW-1 }\end{array}$ & $\begin{array}{c}\text { Migade } \\
\text { Uganda } \\
\text { MG-1 }\end{array}$ & $\begin{array}{c}\text { Mayouom } \\
\text { Cameroon } \\
\text { sand-p MY03 }\end{array}$ & $\begin{array}{c}\text { Huambo } \\
\text { Angola } \\
\text { Sa Bandeira }\end{array}$ \\
\hline 48.76 & 49.98 & 49.90 & 46.61 & 72.21 \\
32.24 & 35.97 & 35.62 & 33.29 & 15.02 \\
0.62 & 0.02 & 0.05 & 3.96 & 0.40 \\
2.75 & 0.34 & 0.54 & 1.46 & 0.29 \\
0.02 & 0.05 & 0.04 & $<\mathrm{dl}$ & 0.06 \\
0.52 & 0.33 & 0.34 & $<\mathrm{dl}$ & 0.80 \\
0.06 & $<0.010$ & $<0.01$ & $<\mathrm{dl}$ & 2.37 \\
0.01 & 0.03 & 0.04 & $<\mathrm{dl}$ & 3.23 \\
1.65 & 0.99 & 0.78 & 0.94 & 3.86 \\
0.01 & 0.06 & 0.11 & 0.40 & 0.08 \\
12.48 & 12.61 & 12.85 & 13.97 & 1.00 \\
99.13 & 100.35 & 100.23 & 99.87 & 100.50 \\
92 & 97 & 97 & 97 & 52 \\
\hline
\end{tabular}




\begin{tabular}{|c|c|c|c|c|c|c|c|}
\hline ppm & $\begin{array}{c}\text { Caluquembe } \\
\text { Angola } \\
\text { KU6B }\end{array}$ & $\begin{array}{c}\text { Caluquembe } \\
\text { Angola } \\
\text { KU6D }\end{array}$ & $\begin{array}{c}\text { Caluquembe } \\
\text { Angola } \\
\text { KL13-2 }\end{array}$ & $\begin{array}{c}\text { Caluquembe } \\
\text { Angola } \\
\mathrm{K} 6 \mathrm{E}\end{array}$ & $\begin{array}{c}\text { Caluquembe } \\
\text { Angola } \\
\text { KLB } 10 \\
\end{array}$ & $\begin{array}{c}\text { Caluquembe } \\
\text { Angola } \\
\text { L1 }\end{array}$ & $\begin{array}{c}\text { Buwambo } \\
\text { Uganda } \\
\text { BW-1 }\end{array}$ \\
\hline $\mathrm{Be}$ & 4 & 3 & 3 & 3 & 3 & 4 & n.d. \\
\hline V & 101 & 69 & 51 & 54 & 77 & 74 & $<15$ \\
\hline $\mathrm{Cr}$ & $<20$ & $<20$ & $<20$ & 30 & $<20$ & 20 & 4.47 \\
\hline Co & 6 & 5 & 10 & 8 & 7 & 7 & 1.3 \\
\hline $\mathrm{Ni}$ & $<20$ & $<20$ & $<20$ & $<20$ & $<20$ & $<20$ & 19 \\
\hline $\mathrm{Cu}$ & 10 & $<10$ & 50 & 20 & 50 & 10 & 52 \\
\hline $\mathrm{Zn}$ & 60 & 50 & 50 & 50 & 90 & 60 & 16 \\
\hline $\mathrm{Ga}$ & 36 & 29 & 42 & 31 & 34 & 26 & n.d. \\
\hline $\mathrm{Ge}$ & 2 & 2 & 2 & 2 & 2 & 2 & n.d. \\
\hline As & $<5$ & $<5$ & 5 & $<5$ & $<5$ & $<5$ & 0.12 \\
\hline $\mathrm{Rb}$ & 167 & 155 & 54 & 113 & 206 & 130 & 58.3 \\
\hline $\mathrm{Sr}$ & 40 & 41 & 65 & 20 & 44 & 22 & 39.1 \\
\hline $\mathrm{Zr}$ & 368 & 281 & 337 & 430 & 278 & 162 & 142 \\
\hline $\mathrm{Nb}$ & 18 & 15 & 22 & 24 & 14 & 17 & 6 \\
\hline Mo & $<2$ & $<2$ & 2 & $<2$ & $<2$ & $<2$ & n.d. \\
\hline $\mathrm{Ag}$ & 1.3 & 1 & 1.3 & 1.5 & 1 & $<0.5$ & n.d. \\
\hline In & $<0.2$ & $<0.2$ & $<0.2$ & $<0.2$ & $<0.2$ & $<0.2$ & n.d. \\
\hline Sn & 3 & 2 & 4 & 4 & 5 & 3 & n.d. \\
\hline $\mathrm{Sb}$ & $<0.5$ & $<0.5$ & $<0.5$ & $<0.5$ & $<0.5$ & $<0.5$ & n.d. \\
\hline Cs & 3.3 & 3 & $<0.5$ & 5.9 & 2.4 & 3.9 & 2.27 \\
\hline $\mathrm{Ba}$ & 595 & 683 & 1090 & 222 & 871 & 307 & 63.2 \\
\hline $\mathrm{Bi}$ & $<0.4$ & $<0.4$ & 1.5 & $<0.4$ & $<0.4$ & 0.6 & n.d. \\
\hline $\mathrm{Hf}$ & 9.8 & 7.5 & 8.7 & 10.7 & 6.9 & 4.9 & 0.66 \\
\hline $\mathrm{Ta}$ & 1.8 & 1.7 & 2.3 & 3.1 & 1.7 & 1.6 & 0.34 \\
\hline W & 5 & 3 & 13 & 6 & 6 & 4 & n.d. \\
\hline $\mathrm{TI}$ & 0.8 & 0.7 & 0.5 & 0.6 & 0.9 & 0.5 & n.d. \\
\hline $\mathrm{Pb}$ & 36 & 36 & 40 & 38 & 22 & 26 & n.d. \\
\hline Th & 25.1 & 20.1 & 48.6 & 31.7 & 16.9 & 17.9 & 1.66 \\
\hline$\underline{U}$ & 7.1 & 6 & 5.6 & 17.2 & 16.1 & 5.9 & 0.84 \\
\hline
\end{tabular}




\begin{tabular}{|c|c|}
\hline Migade & Mayouom \\
\hline Uganda & Cameroon \\
\hline MG-1 & sand-p MY03 \\
\hline n.d. & $<\mathrm{dl}$ \\
\hline$<15$ & 718 \\
\hline 10.9 & 294 \\
\hline 1.75 & 1.8 \\
\hline 24 & 5.4 \\
\hline 105 & n.d. \\
\hline 24 & 43.2 \\
\hline n.d. & 38 \\
\hline n.d. & 1.77 \\
\hline 0.23 & n.d. \\
\hline 58 & 17.3 \\
\hline 65.9 & 383 \\
\hline 139 & 489 \\
\hline 6 & 57.9 \\
\hline n.d. & 4.08 \\
\hline n.d. & n.d. \\
\hline n.d. & 0.18 \\
\hline n.d. & 3.51 \\
\hline n.d. & n.d. \\
\hline 3.61 & 1.01 \\
\hline 114 & 644 \\
\hline n.d. & n.d. \\
\hline 0.86 & 11.2 \\
\hline 0.38 & 4.44 \\
\hline n.d. & 0.8 \\
\hline n.d. & n.d. \\
\hline n.d. & 9.62 \\
\hline 1.25 & 6.86 \\
\hline 1 & 1.75 \\
\hline
\end{tabular}




\begin{tabular}{|c|c|c|c|c|c|c|c|c|c|}
\hline $\mathrm{ppm}$ & $\begin{array}{l}\text { Angola } \\
\text { KU6B }\end{array}$ & $\begin{array}{l}\text { Angola } \\
\text { KU6D }\end{array}$ & $\begin{array}{l}\text { Angola } \\
\mathrm{KL} 13-2 \\
\end{array}$ & $\begin{array}{c}\text { Angola } \\
\mathrm{K} 6 \mathrm{E} \\
\end{array}$ & $\begin{array}{r}\text { Angola } \\
\text { KLB } 10 \\
\end{array}$ & $\begin{array}{c}\text { Angola } \\
\text { L1 } \\
\end{array}$ & $\begin{array}{c}\text { Uganda } \\
\text { BW-1 }\end{array}$ & $\begin{array}{c}\text { Uganda } \\
\text { MG-1 }\end{array}$ & $\begin{array}{c}\text { Cameroon } \\
\text { sand-p MY03 }\end{array}$ \\
\hline La & 57.5 & 53.1 & 138 & 91.3 & 44.6 & 27.4 & 101 & 215 & 120 \\
\hline $\mathrm{Ce}$ & 92.2 & 114 & 232 & 156 & 67 & 67 & 37.5 & 143 & 243 \\
\hline $\operatorname{Pr}$ & 14 & 12.9 & 29.5 & 19.4 & 9.59 & 5.23 & n.d. & n.d. & 27.3 \\
\hline $\mathrm{Nd}$ & 50.8 & 46.2 & 103 & 67.5 & 32.6 & 18.4 & 51.5 & 159 & 96.5 \\
\hline $\mathrm{Sm}$ & 8.9 & 8.5 & 17.5 & 12.1 & 5.3 & 3 & 9.69 & 15.8 & 20.3 \\
\hline $\mathrm{Eu}$ & 1.74 & 1.69 & 3.8 & 2.37 & 1.1 & 0.65 & 2.16 & 2.25 & 5 \\
\hline $\mathrm{Gd}$ & 6 & 5.6 & 11.8 & 8.4 & 3.5 & 2.1 & 5.51 & 4.61 & 17.4 \\
\hline $\mathrm{Tb}$ & 0.8 & 0.8 & 1.7 & 1.3 & 0.5 & 0.4 & 0.9 & 0.71 & 2.34 \\
\hline Dy & 4.7 & 4.1 & 10.4 & 7.4 & 2.8 & 2 & n.d. & n.d. & 12.7 \\
\hline Ho & 0.9 & 0.7 & 2 & 1.4 & 0.5 & 0.4 & n.d. & n.d. & 2.09 \\
\hline $\mathrm{Er}$ & 2.6 & 2.2 & 6 & 3.9 & 1.7 & 1.2 & n.d. & n.d. & 4.86 \\
\hline $\mathrm{Tm}$ & 0.41 & 0.32 & 0.9 & 0.59 & 0.29 & 0.19 & 0.26 & 0.29 & 0.7 \\
\hline $\mathrm{Yb}$ & 2.8 & 2.2 & 6 & 4.1 & 2.2 & 1.4 & 1.21 & 1.03 & 4.1 \\
\hline Lu & 0.45 & 0.35 & 0.9 & 0.64 & 0.36 & 0.21 & 0.14 & 0.1 & 0.6 \\
\hline Sc & 14 & 11 & 14 & 15 & 12 & 14 & 1.2 & 1.89 & 0 \\
\hline$Y$ & 26 & 20 & 60 & 39 & 16 & 12 & 10 & 8 & 48.3 \\
\hline$\sum$ REE & 243.8 & 252.66 & 563.5 & 376.4 & 172.04 & 129.58 & 209.87 & 541.79 & 556.89 \\
\hline$\sum$ LREE & 225.14 & 236.39 & 523.8 & 348.67 & 160.19 & 121.68 & 201.85 & 535.05 & 512.1 \\
\hline$\sum$ HREE & 18.66 & 16.27 & 39.7 & 27.73 & 11.85 & 7.9 & 8.02 & 6.74 & 44.79 \\
\hline LREE/HREE & 12.07 & 14.53 & 13.19 & 12.57 & 13.52 & 15.40 & 25.17 & 79.38 & 11.43 \\
\hline $\mathrm{La} / \mathrm{Th}$ & 2.29 & 2.64 & 2.84 & 2.88 & 2.64 & 1.53 & 60.84 & 172.00 & 17.49 \\
\hline Y/HREE & 1.39 & 1.23 & 1.51 & 1.41 & 1.35 & 1.52 & 1.25 & 1.19 & 1.08 \\
\hline
\end{tabular}




\begin{tabular}{cc} 
UCC & C1Ch. \\
\hline 31 & 0.237 \\
63 & 0.613 \\
7.1 & 0.0928 \\
27 & 0.457 \\
4.7 & 0.148 \\
1 & 0.0563 \\
4 & 0.199 \\
0.7 & 0.0361 \\
3.9 & 0.246 \\
0.83 & 0.0546 \\
2.3 & 0.16 \\
0.3 & 0.0247 \\
2 & 0.161 \\
0.31 & 0.0246 \\
14 & 5.92 \\
21 & 0.026
\end{tabular}




\begin{tabular}{|c|c|c|c|c|c|c|}
\hline & $\begin{array}{l}\text { Caluquembe } \\
\text { Angola } \\
\text { whole rock } \\
\text { granite }\end{array}$ & $\begin{array}{l}\text { Mayouom } \\
\text { western } \\
\text { Cameroon } \\
\text { sand-poor } \\
\text { kaolin } \\
\text { mylonite } \\
\end{array}$ & $\begin{array}{l}\text { Koutaba } \\
\text { western } \\
\text { Cameroon } \\
\text { whole rock } \\
\text { granite } \\
\end{array}$ & $\begin{array}{c}\text { Buwambo } \\
\text { central } \\
\text { Uganda } \\
\text { whole rock } \\
\text { granite }\end{array}$ & $\begin{array}{c}\text { Migade } \\
\text { Central } \\
\text { Uganda } \\
\text { whole rock } \\
\text { granite } \\
\end{array}$ & $\begin{array}{l}\text { Mevaiela } \\
\text { Angola } \\
<2 \mu \mathrm{m} \\
\text { fraction } \\
\text { anorthosite }\end{array}$ \\
\hline kaolinite & 50 to 87 & 76 to 85 & 32 to 51 & 82 to 94 & 84 to 91 & $\approx 100$ \\
\hline quartz & 0 to 23.5 & 2 to 9 & 32 to 52 & 0 to 10 & 5 to 10 & detected \\
\hline muscovite/illite & 1 to 27 & 1 to 8 & up to 12 & 3 to 6 & 3 to 5 & detected \\
\hline feldspars & 2 to 21 & n.d. & 0 to 4 & 1 to 4 & 1 to 2 & detected \\
\hline anatase & n.d. & 3.7 to 4 & n.d. & n.d. & n.d. & n.d. \\
\hline hematite/goethite & 0 to 1.6 & 0.6 to 1.4 & 6 to 7 & n.d. & n.d. & n.d. \\
\hline \multirow[t]{3}{*}{ pyrophilite } & n.d. & n.d. & n.d. & n.d. & n.d. & n.d. \\
\hline & & & Nkalih & & & \\
\hline & this work & $\begin{array}{c}\text { Njoya et al., } \\
2006\end{array}$ & $\begin{array}{c}\text { Mefire et al., } \\
2015\end{array}$ & $\begin{array}{c}\text { Nyakairu et } \\
\text { al., } 2001\end{array}$ & $\begin{array}{l}\text { Nyakairu et } \\
\text { al., } 2002\end{array}$ & $\begin{array}{c}\text { Saviano et } \\
\text { al., } 2005\end{array}$ \\
\hline
\end{tabular}




\begin{tabular}{|c|c|c|c|c|}
\hline $\begin{array}{c}\text { Grahamstow } \\
\text { n South } \\
\text { Africa } \\
\text { Witteberg } \\
\text { shale } \\
\text { granite } \\
\end{array}$ & $\begin{array}{c}\text { Makoro } \\
\text { southheaster } \\
\mathrm{n} \text { Botswana } \\
\text { whole rock } \\
\text { arkose }\end{array}$ & $\begin{array}{l}\text { Zhanjiang, } \\
\text { Longyan, } \\
\text { Guangdong } \\
\text { province } \\
\text { China } \\
\text { granite } \\
\end{array}$ & $\begin{array}{l}\text { Otovice } \\
\text { Czech } \\
\text { Republic } \\
\text { granite } \\
\end{array}$ & $\begin{array}{l}\text { Cornwall } \\
\text { south-west } \\
\text { England } \\
\text { granite } \\
\end{array}$ \\
\hline 20 to 70 & major & 96 & 82 to 92 & 81 to 93 \\
\hline 30 to 60 & minor & 0 to 1 & 1 to 2 & 1 to 2 \\
\hline 10 to 25 & trace & 3 to 4 & 4 to 16 & 4 to 15 \\
\hline 5 & trace & 0 & n.d. & n.d. \\
\hline n.d. & n.d. & n.d. & n.d. & n.d. \\
\hline n.d. & trace & n.d. & n.d. & n.d. \\
\hline up to 35 & n.d. & n.d. & n.d. & n.d. \\
\hline $\begin{array}{c}\text { Heckroodt, } \\
1991\end{array}$ & Ekosse, 2000 & $\begin{array}{c}\text { Wilson et al., } \\
1997\end{array}$ & $\begin{array}{c}\text { Wilson and } \\
\text { Jiranek, } 1995\end{array}$ & $\begin{array}{c}\text { Wilson and } \\
\text { Jiranek, } 1995\end{array}$ \\
\hline
\end{tabular}

